\author{
Contato \\ Rua Cora Coralina, 100 \\ Cidade Universitária Zeferino Vaz \\ 13083-896 - Campinas - SP \\ luregi@unicamp.br
}

\section{ANDRÉ DO COUTO GODINHO: HOMEM PRETO, FORMADO EM COIMBRA, MISSIONÁRIO NO CONGO EM FINS DO SÉCULO XVIII}

\section{Lucilene Reginaldo*}

Universidade Estadual de Campinas Campinas - São Paulo - Brasil

\title{
Resumo
}

O fio condutor deste texto é a trajetória de um homem de cor livre nascido na vila de Mariana, no ano de 1720, tendo falecido no Reino do Congo, em data desconhecida, provavelmente no último decênio do século XVIII. Entre as Minas Gerais e o Reino do Congo, vários anos vividos em Coimbra e Lisboa demarcaram a trajetória de André do Couto Godinho. A narrativa, aparentemente excepcional, não se restringe entretanto a episódios da vida pessoal de Godinho, ao contrário, trata de coletivos mais amplos, constituindo-se, quiçá, em uma "janela privilegiada" para o mundo dos homens de cor livres em diferentes localidades do Império português, na segunda metade dos Setecentos. Assim, ao seguir os passos de André Godinho, focalizo contextos históricos que dão sentido e podem, ao mesmo tempo, ser reinterpretados à luz das possibilidades, escolhas e limitações que constituíram sua história pessoal.

\section{Palavras- chave}

Homens livres de cor, século XVIII - Reino do Congo, século XVIII - Império português

* Doutora em História Social pela Unicamp. Professora doutora de História da África, Departamento de História, Instituto de Filosofia e Ciências Humanas - IFCH/Unicamp. Bolsista de Produtividade - CNPq. 


\section{Contact \\ Rua Cora Coralina, 100 Cidade Universitária Zeferino Vaz 13083-896 - Campinas - SP luregi@unicamp.br}

\section{ANDRÉ DO COUTO GODINHO: BLACK, TRAINED IN COIMBRA, MISSIONARY IN THE CONGO IN THE LATE 18TH CENTURY}

\author{
Lucilene Reginaldo
}

Universidade Estadual de Campinas

Campinas - São Paulo - Brazil

\begin{abstract}
This paper follows the path of a free man of color who was born in 1720 in the Brazilian captaincy of Minas Gerais, in the town of Mariana, and died in the Kingdom of Kongo, probably during the last decade of the eighteenth century. Between the beginning of his life, in Brazil, and its end, in Africa, André do Couto Godinho spent a number of years in Portugal, in the cities of Coimbra and Lisbon. While his life story is certainly an extraordinary one, the present narrative does not confine itself to his individual trajectory; on the contrary, it uses his life as a lens for seeing into the world of free men of color in different parts of the Portuguese empire during the second half of the 1700s. Thus, in retracing André Godinho's footsteps, I also examine the historical contexts that defined the possibilities, choices and limitations of his personal history.
\end{abstract}

\title{
Keywords
}

Free man of color, XVIII century - Kingdom of Kongo, XVIII century - Portuguese Empire 


\section{Homem preto, natural dos Brasis ${ }^{1}$}

André do Couto Godinho desembarcou na cidade de São Paulo de Assunção de Luanda, sede do bispado de Angola e Congo, no dia 4 de dezembro de 1779. Godinho era um dos 21 missionários que chegavam a Luanda, recrutados em todo Portugal e enviados a conquista de Angola pelo ministro Martinho de Mello e Castro com aval e recomendação da rainha d. Maria I. A nau Nossa Senhora de Belém havia deixado o Tejo no dia 2 de julho do mesmo ano, levando a bordo o governador e capitão general do Reino de Angola, d. José Gonçalves Câmara, e, além dele, "o governador de Benguela, o Juiz de Fora da mesma cidade, duas companhias de soldados, uma de artilharia, outra de armada", marinheiros, pilotos, um grande número de degredados, num total de quase seiscentas pessoas. ${ }^{2}$ Dos 22 missionários que embarcaram no Tejo, 21 alcançaram o seu destino. O padre Matias da Encarnação, acometido de um violento ataque de gota, desembarcou no Rio de Janeiro em 22 de setembro. ${ }^{3}$ Na certa, não suportou os rigores da viagem! Os transtornos não devem ter sido de todo imprevistos, pois a Nossa Senhora de Belém deixou um Tejo num período pouco apropriado para a travessia atlântica. ${ }^{4} \mathrm{O}$ trajeto entre a ilha da Madeira e o Rio de Janeiro não foi tranquilo, pois "um vento

\footnotetext{
1 Nos documentos pesquisados, André do Couto Godinho é sempre identificado como "homem preto". Nos séculos XVIII e XIX, frequentemente o termo preto era indicativo da origem africana; neste caso, é certo que não se trata de um natural da África, mas de um negro, não miscigenado, nascido na América portuguesa. Os "Brasis" como lugar de origem de Godinho também são referidos na documentação. Evidentemente, nem em termos políticos, nem em termos das fronteiras geográficas, há uma correspondência exata com o estado nacional brasileiro criado no século XIX.

2 Breve relação e sumário da viagem que na sua nau Nossa Senhora de Belém fez o governo e missionários que sua majestade expediu para o Reino de Angola no mês de junho de 1779. Instituto dos Arquivos Nacionais/ Torre do Tombo - IAN/TT. Miscelâneas manuscritas, nº 1.103, fl. 421.

3 A escala no Rio de Janeiro era comum e muito recomendada nas viagens marítimas que partiam de Lisboa com destino a Angola. O objetivo principal era beneficiar-se dos ventos favoráveis das correntezas complementares que tornavam a travessia entre a América portuguesa e Angola muito mais rápida e segura. Ver, especialmente: ALENCASTRO, Luís Felipe. $O$ trato dos viventes: $A$ formação do Brasil no Atlântico sul, séculos XVI e XVII. São Paulo: Companhia das Letras, 2000, p. 61-63.

4 Segundo Alencastro, para garantir uma boa viagem "entre a Metrópole e a conquista americana, devia-se observar um calendário marítimo preciso, uma janela sazonal delimitada. Largava-se de Lisboa entre os dias 15 e 25 de outubro para lançar âncora em Recife cerca de dois meses mais tarde. (...) Fora destes prazos, o tempo de cada uma das etapas da viagem dobrava - no mínimo -, com aumento exponencial do risco da tripulação, exposta às tempestades sazonais, à sede e às doenças nas calmarias ao largo da zona equatorial africana". ALENCASTRO, Luís Felipe. $O$ trato dos viventes, op. cit., p. 57.
} 
contrário pela proa" fez a nave bordejar por mais de 20 dias e, em consequência, faltaram água e mantimentos, e o escorbuto fez numerosas vítimas entre passageiros e tripulantes. ${ }^{5}$ A viagem para Luanda foi igualmente difícil, mesmo para aqueles que, como Godinho, já haviam enfrentado os perigos e a imprevisibilidade do tenebroso oceano. Após enfrentarem ventos desfavoráveis, tormentas e desvios da rota original, em 3 de dezembro de 1779, o governador e o juiz de fora de Benguela puderam desembarcar no seu destino. E, no dia seguinte, 4 de dezembro, juntamente com os demais missionários do reino, Godinho dirigiu-se à Sé de Luanda, para apresentar-se ao frei Luís da Anunciação e Azevedo, naqueles tempos, bispo de Angola e Congo.

Luanda, primeira fundação europeia no ocidente africano, certamente impressionou o missionário nascido nas Minas Gerais por vários motivos. Com uma conformação urbanística bem definida, nas últimas décadas do século XVIII, Luanda estava dividida em centro e periferia. O centro subdividia-se em duas zonas, uma administrativa - cidade alta - e uma zona comercial - cidade baixa. Na cidade alta se concentrou o centro dos poderes político, militar e religioso da conquista: o palácio do governo, a residência episcopal, a matriz da freguesia da Sé (Nossa Senhora da Conceição), a Santa Casa de Misericórdia e a maioria dos conventos da cidade. A cidade baixa abrangia a zona comercial e a periferia da cidade. ${ }^{6}$ A maioria de seus moradores era direta ou indiretamente ligada ao tráfico de escravos. "Era constituída, sobretudo, por quintais, onde eram instalados os escravos que aguardavam embarque e pelas palhotas dos escravos que trabalhavam em Luanda". A maior parte da periferia e da zona comercial pertencia à freguesia de Nossa Senhora dos Remédios. ${ }^{7}$

O nome do padre André Couto Godinho encabeçava a lista dos missionários enviados ao Reino de Angola e, além disso, destacava-se pela cuidadosa apresentação. Numa extensa carta datada do dia 22 de junho de 1779, o ministro Martinho de Mello e Castro informa ao bispo de Angola, d. Luís da Anunciação, as providências tomadas pelo Paço "diante do lastimável estado dos assuntos religiosos" no bispado africano. De todas, a mais importante foi a adesão voluntária de mais de duas dezenas de missionários, convocados

\footnotetext{
Viagem do Congo do missionário fr. Rafael Castello de Vide, hoje bispo de S. Tomé (1788). Academia Real das Ciências de Lisboa, série vermelha, manuscrito 396, p. 15.

${ }^{6}$ A periferia era constituída pelo grupo de ilhas localizadas em frente à cidade, além da região oriente e norte da zona comercial.

7 VENÂNCIO, José Carlos. A economia de Luanda e hinterland no século XVIII: Um estudo de sociologia histórica. Lisboa: Editorial Estampa, 1996, p. 32-37.
} 
em todo Portugal e que seguiam em missão para Angola. Na mesma correspondência, o ministro distingue o padre André do Couto Godinho, "clérigo secular Preto, formado em Cânones, de muita virtude, e excelentes qualidades, pelas quais mereceu a geral estimação de toda a Corte, e que passa a essa Conquista com o único fim de se empregar na Missão do Congo". ${ }^{8}$

\section{Imagem 1}

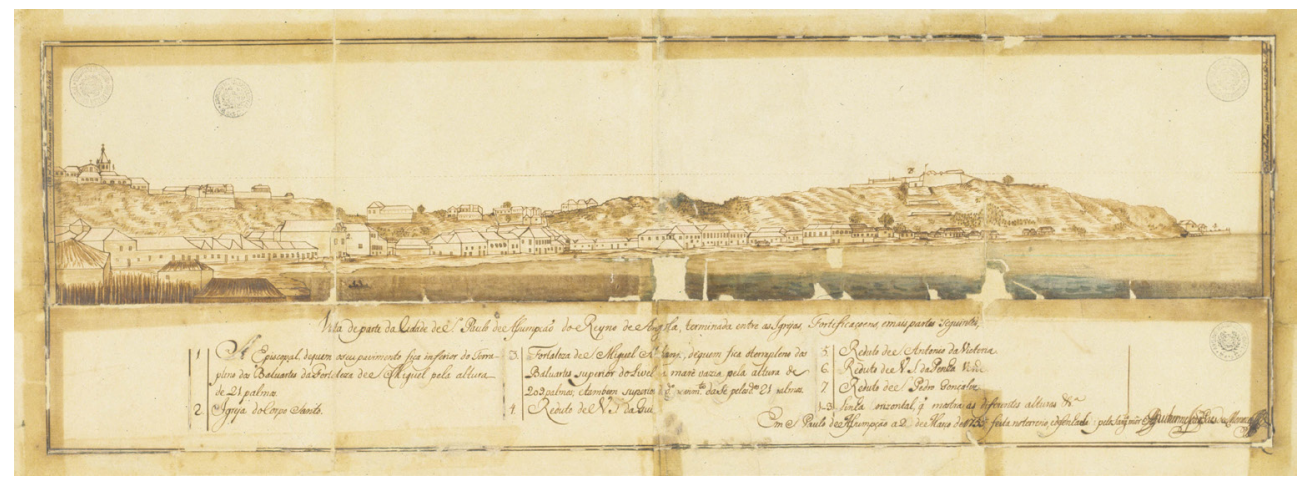

Guilherme Paes de Menezes - http://www.nead.unama.br/site/bibdigital/cartografia_potuguesa/ textos/MEDIAS1/3.1.htm

Vista panorâmica de Luanda no ano de 1755 por Guilherme Paes de Menezes. Domínio Público.

A aparência física do padre Godinho e, possivelmente, sua condição social, não eram propriamente excepcionais no cenário luandense. Em 1773, uma contagem parcial da população de Luanda, distribuída pelas duas freguesias, apresentava os seguintes dados: "pessoas brancas 251 (214 do sexo masculino e 37 do feminino), com 787 escravos; pessoas pardas 138 (106 do sexo masculino e 32 do sexo feminino) com 187 escravos; pessoas pretas livres 147 (143 do sexo masculino e 4 do feminino) com 9 escravos".9 Observe-

\footnotetext{
8 BRÁSIO, padre António. A missão de 1779. Revista Portuguesa de História, tomo XVI. Separata. Coimbra, 1978, p. 358-359. Ver também: Relação dos missionários que chegaram ao Reino de Angola por missionários no ano de 1779. Arquivo Histórico Ultramarino - AHU, Angola, cx. 62/63, doc. 97.

9 COUTO, Carlos. Os capitães-mores em Angola no século XVIII. Luanda: Instituto de Investigação Científica de Luanda, 1972, p. 109. Segundo Curto e Gervais: "O relatório de 1773 forneceu informações numéricas sobre: brancos, mulatos livres e escravizados, e negros livres e homens escravos capazes de portar armas (i. e., aqueles entre quinze e cinquenta anos de idade); brancos, mulatos livres e mulheres negras livres; e as tropas do governo por cor. Dois grupos
} 
rev. hist. (São Paulo), n. 173, p. 141-174, jul.-dez., 2015 http://dx.doi.org/10.11606/issn.2316-9141.rh.2015.100874
Lucilene Reginaldo

André do Couto Godinho: homem preto, formado em Coimbra, missionário no Congo em fins do século XVIII

se que a soma dos pardos e africanos livres, 258 pessoas no total, superava o número de civis de origem europeia. Estes números chamam a atenção para a importância da população "de cor" e livre na vida social, política e econômica de Angola. Para a década seguinte, temos dados mais completos referentes aos pardos e africanos livres moradores em Luanda. ${ }^{10} \mathrm{Na}$ cidade baixa, habitavam 1.004 brancos, 1.103 pardos livres, 137 pardos escravos, 864 negros livres e 3.592 negros escravos. Na cidade alta, os brancos somavam 512 indivíduos, 313 pardos livres, 217 pardos escravos, 382 negros livres e 1.737 negros escravos. ${ }^{11}$ É interessante observar que a maioria dos pardos e africanos livres, 1.416 e 1.246 indivíduos respectivamente, vivia na cidade baixa. Nota-se ainda que, num quadro de grande crescimento populacional registrado no censo de 1781, pardos e africanos livres representavam a maioria dos moradores livres da cidade, somando 2.662 pessoas, em um total de 4.178 indivíduos. Salta aos olhos o grande número de pardos e negros livres, ou seja, um significativo número de gente de cor que, à semelhança de Godinho, vivia como livre e ocupava diferentes lugares sociais tais como: prestadores de serviços, funcionários da administração local, militares e até mesmo sacerdotes. Guardadas as consideráveis diferenças em termos históricos e demográficos, também nas Minas Gerais, o contingente de pessoas livres de cor salta aos olhos, pelo menos desde o início do século XVIII.

André do Couto Godinho foi batizado na freguesia do Sumidouro, bispado de Mariana, em outubro de $1720 .{ }^{12}$ A vila fundada em 1711 foi, até o início do século XIX, o mais importante distrito escravista das Minas Gerais.

\footnotetext{
de indivíduos, porém, estavam totalmente excluídos da contagem: mulatos escravizados e mulheres negras, que teriam representado uma significativa porção da população total; e homens civis abaixo de quinze e acima de cinquenta anos de idade. A contagem de 1781 foi ao mesmo tempo mais completa e mais abrangente (...)". CURTO, José C. \& GERVAIS, Raymond R. A dinâmica demográfica de Luanda no contexto do tráfico de escravos do Atlântico Sul, 1781-1844. Topoi, Rio de Janeiro, UFRJ, nº 4, 2002, p. 91.

${ }^{10}$ A partir do último quartel do século XVIII, começaram a ser produzidas estatísticas mais abrangentes sobre a população de Luanda. Este empreendimento é resultante da preocupação do governo de Pombal por informações quantitativas mais precisas sobre os residentes nos territórios portugueses ultramarinos. Mesmo após o fim da "era Pombal", a mesma postura foi mantida pelas autoridades portuguesas. Além deste primeiro censo realizado em 1772, outros cinco censos foram realizados na cidade de Luanda nos últimos decênios do século XVIII (1781, 1796, 1797, 1798, 1799). CURTO, José \& GERVAIS, Raymond R. A dinâmica demográfica de Luanda no contexto do tráfico de escravos do Atlântico Sul, op. cit., p. 86- 87; 110-111.

${ }^{11}$ VENÂNCIO, José Carlos. A economia de Luanda e hinterland no século XVIII, op. cit., p. 212.

${ }^{12}$ RUBERT, Arlindo. A Igreja no Brasil, vol. 3 (1700-1822). Santa Maria, Rio Grande do Sul: Editora Palloti, 1983, p. 340.
} 
A presença de grande número de escravos era decorrente do surgimento e expansão da atividade mineradora na região, que também impulsionou a urbanização e a instalação da máquina administrativa da Coroa portuguesa. Nesta, como em outras regiões mineradoras, circulavam numerosos escravos, mas também libertos e homens e mulheres "de cor", livres. ${ }^{13}$ No século XVIII, a população negra e mestiça foi maioria incontestável nas Minas em geral e na vila de Mariana em particular.

André era filho legítimo dos pretos Victoria do Couto e Pedro Alvares. ${ }^{14}$ Alguns indícios sugerem supostos vínculos entre o casal de pretos e a única família Couto Godinho identificada na vila de Mariana no período em foco. António do Couto Godinho, natural do bispado do Porto, em Portugal, parece ter sido o patriarca da família marianense, radicada na freguesia do Sumidouro. Não foi possível saber o ano da chegada de Antonio Godinho às Minas Gerais, mas, muito provavelmente, já estava ali bem estabelecido no ano de 1728, quando se casa com Natália Rodrigues, na ocasião com 18 anos de idade e natural da freguesia mineira de Cachoeira do Campo. ${ }^{15}$ Certamente, a informação mais relevante sobre a jovem Natália, pelo menos para os seus futuros descendentes, foi o reconhecimento público da origem e condição de sua avó Cristina da Silva, uma liberta de nação angola. Ainda não foi possível atestar uma relação direta entre o casal Victória e Pedro com a família Couto Godinho. Entretanto, além da adoção dos sobrenomes - Victória adotou apenas um, mas seu filho livre André assinava os dois -, outro fato parece indicar uma proximidade entre os pais de André e a família Couto Godinho.

Francisco do Couto Godinho, um dos filhos do casal António e Natália, estudou Medicina na Universidade de Coimbra, ingressando em 1752 e con-

\footnotetext{
${ }^{15}$ Sobre as alforrias na região das Minas no século XVIII, especialmente na vila de Mariana ver: PAIVA, Eduardo França. Coartações e alforrias nas Minas Gerais do século XVIII: as possibilidades de libertação escrava no principal centro colonial. Revista de História. São Paulo: USP, n. 133, 1995, p. 49-57; MONTI, Carlos G. O processo de alforria (Mariana 1750-1779). Dissertação de mestrado em História, Faculdade de Filosofia e Ciências Humanas, Universidade de São Paulo, 2011; PINHEIRO, Fernanda Aparecida Domingos. Em defesa da liberdade. Libertos e livres de cor nos tribunais do Antigo Regime português (Mariana e Lisboa, 1720-1819). Tese de doutorado em História, Instituto de Filosofia e Ciências Humanas, Unicamp, 2013. Sobre os negros e mulatos de cor e livres na América portuguesa, com destaque para as Minas Gerais, ver o livro clássico de Russel-Wood, especialmente os capítulos 3 e 4. RUSSEL-WOOD, A. J. R. Escravos e libertos no Brasil colonial. Tradução de Maria Beatriz Medina. Rio de Janeiro: Civilização Brasileira, 2005.

${ }^{14}$ Processos de justificação "de gênere", para ordenação sacerdotal (1758). Arquivo da Universidade de Coimbra - AUC, cx. 32.

${ }^{15}$ Processo de habilitação matrimonial. Antonio do Couto Godinho - Natália Rodrigues, 1728. Arquivo Eclesiástico de Mariana - AEM.
} 
cluindo o curso no ano de $1756 .{ }^{16}$ André do Couto Godinho também ingressou na Faculdade de Cânones no ano de 1752 e o fato, muito possivelmente, não se tratou de uma mera coincidência. ${ }^{17}$ É possível mesmo aventar que os dois estudantes naturais da freguesia do Sumidouro, carregando os mesmos sobrenomes e, talvez, cultivando algum vínculo pessoal, pudessem ter feito juntos a longa viagem para o reino.

\section{Formado em Cânones}

Até a década de 1720, a maioria dos estudantes originários da América portuguesa na Universidade de Coimbra era oriunda de três principais centros: Bahia, Rio de Janeiro e Pernambuco. A partir de então, os estudantes oriundos da região mineradora passam a destacar-se numericamente. Entre 1741 e 1760, 139 estudantes da capitania de Minas Gerais estavam matriculados nos cursos de Coimbra. Destes, 32 estudantes eram naturais de Mariana. ${ }^{18}$ André e Francisco estavam entre estes estudantes.

A importância de Coimbra na formação das elites coloniais tem sido tratada com muita atenção pela historiografia brasileira. Como afirmou Raminelli, "filhos de militares, comerciantes e proprietários de terras foram enviados à universidade com a intenção de receber formação e, posteriormente, ingressarem na magistratura ou em cargos de prestígio na administração metropolitana e colonial". Prestigiados políticos e naturalistas como José Bonifácio de Andrada e Silva, José da Cunha Azeredo Coutinho, José da Silva Lisboa e Alexandre Rodrigues Ferreira foram bacharéis e doutores formados em Coimbra. ${ }^{19}$ Mesmo reconhecendo a "face parda" de muitos membros da elite, pouco sabemos sobre o significado e o impacto da presença dos homens livres de cor no interior do grande contingente de brasileiros matriculados nas faculdades de Coimbra. A história de Godinho, entre outros aspectos, traz à tona um tema praticamente desconhecido da historiografia luso-brasileira:

\footnotetext{
${ }^{16}$ Processo de habilitação matrimonial. Francisco do Couto Godinho - Maria Pereira de Jesus, 1765. O "defeito da mulatice", bem como sua origem, é mencionado no processo matrimonial das segundas núpcias de Francisco. AEM.

${ }^{17}$ Livros de matrículas. AUC, vol. 70, 1752-1753, fl. 387.

${ }^{18}$ FONSECA, Fernando Taveira. Scientia thesaurus mirabilis: estudantes de origem brasileira na Universidade de Coimbra (1601-1850). Revista Portuguesa de História, tomo 3, vol. 3, 1999, p. 541-42.

${ }^{19}$ DIAS, Maria Odila Leite. Aspectos da Ilustração no Brasil. In: Idem. Interiorização da metrópole. São Paulo: Alameda, 2009, p. 39-126; RAMINELLI, Ronald. Viagens ultramarinas. Monarcas, vassalos e governo a distância. São Paulo: Alameda, 2008, p. 8-9.
} 
a presença de negros e mulatos como estudantes na Universidade de Coimbra. Ele não foi único e, ao seguir seus passos pelos corredores da tradicional instituição, nos deparamos com outros livres de cor naturais dos "Brasis".

André do Couto Godinho fez sua matrícula no curso de Cânones no ano de $1752 .{ }^{20}$ Sua escolha foi certamente informada pela notoriedade do curso. Até a reforma pombalina, a Faculdade de Cânones foi a maior e mais prestigiada de Coimbra, seguida com alguma distância pelas faculdades de Leis e Medicina. ${ }^{21}$ Universidade de nítida predominância jurídica, a primazia do Direito canônico em Coimbra se explica, em grande parte, pelas possibilidades de carreira oferecidas pelo curso, quer na administração eclesiástica, quer na magistratura secular. Por seu turno, o curso de Leis, destinado exclusivamente à formação da magistratura secular, era mais restrito, não permitindo candidatura à carreira eclesiástica. ${ }^{22}$ Assim, além da importância atribuída ao Direito canônico na Igreja pós-tridentina, razões de foro "mundano" são bastante esclarecedoras da grande concentração de estudantes na Faculdade de Cânones da Universidade de Coimbra. ${ }^{23}$

Seguindo o protocolo, no registro de matrícula de André Godinho, constam apenas três informações: nome completo, nome do pai e localidade de origem. Segundo os estatutos vigentes na época, o aluno pagava a modesta quantia de dez réis pelo assento e matrícula. ${ }^{24}$ Se a questão financeira não pesava demasiado no ato de entrada, outros requisitos de admissão eram certamente mais determinantes. A matrícula na Faculdade de Cânones exigia um sólido aprendizado pré-universitário do latim, que deveria ainda ser atestado em exame específico. ${ }^{25}$ Godinho pode ter feito a preparação pré-universitária em Minas Gerais. O sistema educacional singular da região aurífera não foi associado à ação missionária das ordens religiosas, deixando informações importantes sobre seu funcionamento em "registros avulsos de

\footnotetext{
${ }^{20}$ Livros de matrículas. AUC, vol. 70, 1752-1753, fl. 291v.

${ }^{21}$ O marquês de Pombal foi secretário de Estado de Portugal durante o reinado de d. José I (17501777). Figura controversa no cenário europeu, foi protagonista de importantes reformas políticas, econômicas e educacionais. Ver: MAXWELL, Kenneth. Pombal - Paradox of the Enlightenment. Cambridge: Cambridge University Press, 1995. FONSECA, Fernando Taveira da. A Universidade de Coimbra (1700-1771). Estudo social e econômico. Coimbra: Universidade de Coimbra, 1995, p. 48.

${ }^{22}$ FONSECA, Fernando Taveira da. A Universidade de Coimbra (1700-1771), op. cit., p. 128-29.

23 Sobre a Faculdade de Cânones de Coimbra, ver: ANTUNES, Maria do Carmo Faria Gaspar. $A$ Faculdade de Cânones da Universidade de Coimbra. Orgânica interna e projeção científica e cultural de seus lentes. Dissertação de mestrado, Faculdade de Letras, Universidade de Coimbra, 1990.

${ }^{24}$ Estatutos da Universidade de Coimbra (1653). Edição fac-similada. Coimbra: Universidade de Coimbra, 1987.

${ }^{25}$ FONSECA, Fernando Taveira da. A Universidade de Coimbra (1700-1771), op. cit., p. 143.
} 
solicitação de pagamento de ordenados por serviços prestados às Câmaras por professores por elas contratados para ministrar as disciplinas básicas como Gramática e Latim". 26

\section{Imagem 2}

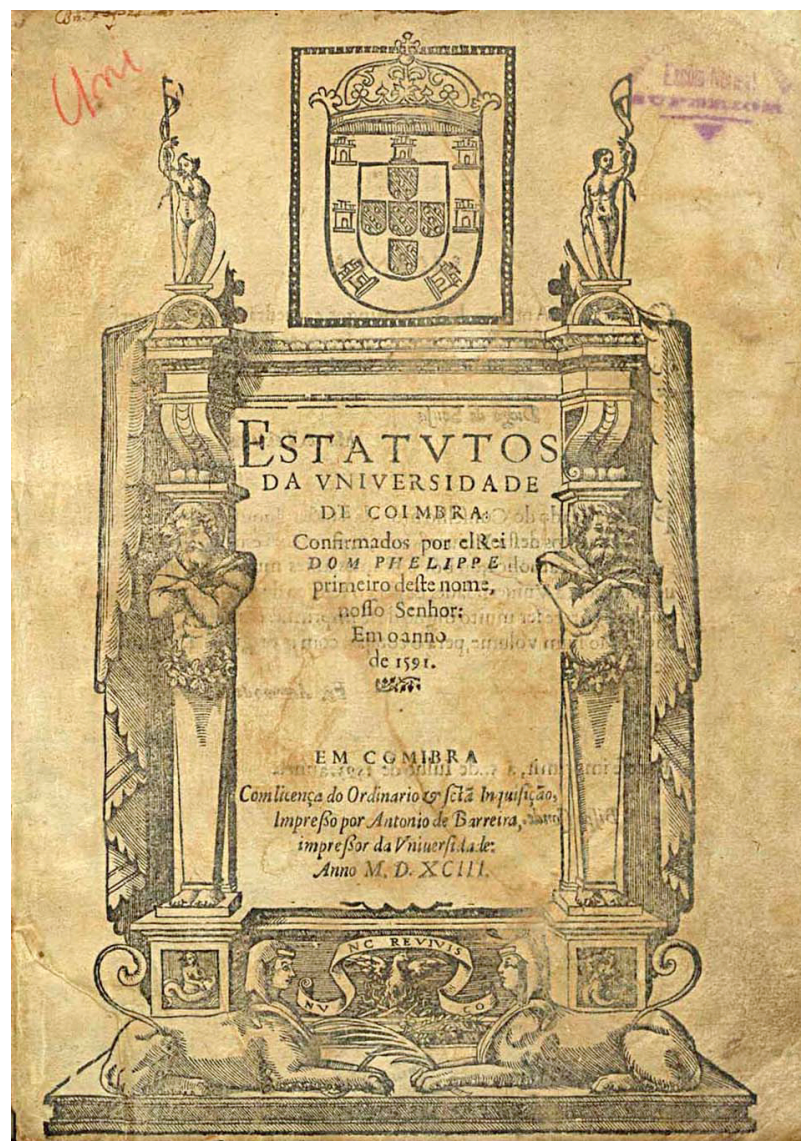

Estatutos da Universidade de Coimbra, 1591. - http://purl.pt/14235/1/index.html\#/3/html Impresso por Antonio de Barreira impressor da Universidade, 1593.

No primeiro ano de estudos em Coimbra, Godinho frequentou o curso de Instituta, pré-requisito e, ao mesmo tempo, preparatório para admissão

\footnotetext{
${ }^{26}$ BOSCHI, Caio. A Universidade de Coimbra e a formação intelectual das elites mineiras coloniais. Revista Estudos Históricos. Rio de Janeiro: Fundação Getúlio Vargas, vol. 4, nº 7, 1991, p. 103.
} 
aos atos e graus e a outros cursos. ${ }^{27}$ No início do quinto ano de curso, mais precisamente no dia 28 de maio de 1757, André Godinho graduou-se bacharel em Cânones, após ser aprovado em exame pelos doutores lentes da Faculdade Manoel Gomes Ferreira e Francisco de Mattos. ${ }^{28}$ Após o ato de conclusões, como era denominado o exame para obtenção do bacharelado, seguiu-se a formatura, realizada em março de 1759. Era requisito para obtenção deste grau, além da apresentação de certidões de frequência em oito cursos de oito meses, dois dos quais em Leis, a apresentação de uma "lição de ponto de vinte e quatro horas", com duração de uma hora. ${ }^{29}$ Godinho submeteu-se ao novo exame, sendo arguido e aprovado pelos doutores lentes José Gomes Monteiro e Caetano Correia Seixas. O resultado do exame no livro de atos e graus chama atenção pela anotação "homem preto", registrada pela primeira vez junto ao nome de André do Couto Godinho nos documentos da Faculdade de Coimbra. ${ }^{30}$ A mesma anotação se repetiu no livro de informações gerais que, estranhamente, não informa sua avaliação de desempenho, registrando no espaço destinado à avaliação o texto "não tem informação". Esta ausência de registro de desempenho deve ter sido decisiva na carreira de André do Couto Godinho.

A leitura de bacharéis no Desembargo do Paço, etapa necessária para o ingresso na carreira da magistratura secular, contava, na primeira metade dos Setecentos, com um número elevado de formados em Cânones. A informação de desempenho no registro "informações gerais" era pré-requisito para que o canonista formado tivesse acesso ao Paço. Assim, a declaração "não tem informação" explicita a decisão da junta de doutores lentes de excluir "liminarmente [o graduando] de poder concorrer a cargos de magistratura vedando-lhe o acesso à leitura no Desembargo do Paço". ${ }^{31}$ Os motivos da exclusão eram registrados com alguma frequência e, em certos casos, podiam resultar de uma penitência. Esta certamente não foi a razão determinante na ausência de registro de desempenho de André Godinho, aprovado no exame de formatura "nemine discrepance" e "sem penitência qualquer". ${ }^{32}$

\footnotetext{
${ }^{27}$ ANTUNES, Maria do Carmo Garcia Faria Gaspar. O ensino da Faculdade de Cânones. Universidade(s). História, memória, perspectivas. vol. 4, 1991. Atas do Congresso. Coimbra: Universidade de Coimbra, 1991, p. 123.

${ }^{28}$ Livros de actos e graus. AUC, vol. 91. 1756-1757, fl. 39.

${ }^{29}$ ANTUNES, Maria do Carmo Garcia Faria Gaspar. O ensino da Faculdade de Cânones, op. cit., p. 124.

${ }^{30}$ Livros de actos e graus. AUC, vol. 93, 1758-1759, fl. 51.

${ }^{31}$ FONSECA, José Taveira da A Universidade de Coimbra (1700-1771), op. cit., p. 259.

${ }^{32}$ Livros de actos e graus. AUC, vol. 93, 1758-1759, fl. 51.
} 
Fonseca identificou 42 registros de informações gerais na Faculdade de Cânones e 50 na de Leis, nos quais constava a declaração "não tem informação". ${ }^{33}$ Em alguns casos, tratava-se de suspeitas de que os recém-formados seriam cristãos novos. ${ }^{34}$ Em 1708, o assento de Bartolomeu Caminha Falcão no registro de informações gerais vem acompanhado da observação de que a anotação de seu desempenho foi negada no ano anterior - negativa também estendida ao seu irmão Manuel Miranda Caminha - pois a junta de lentes "se achava com alguma dúvida para não fazer as ditas informações" ${ }^{35}$ Embora não houvesse qualquer verificação formal de "limpeza de sangue" no ato de matrícula, o que aliás não era sequer previsto nos estatutos da Universidade, na primeira metade do século XVIII, anotações de dúvida sobre a descendência de judeus ou cristãos novos ficaram documentadas especialmente nos registros de habilitação dos formados para o acesso aos prestigiados cargos de magistratura.

Nas sociedades ibéricas, o estigma da "mancha de sangue" e, por conseguinte, a necessidade de prova de "limpeza de sangue" tinha como alvo os cristãos-novos de origem judaica e mulçumana. Assim, a introdução, em 1570, dos estatutos de limpeza de sangue nas três ordens militares portuguesas mencionava apenas a exclusão de mouros e judeus, sem fazer referência a outras origens ou povos. ${ }^{36}$ A expansão dos impérios para a costa americana e africana, ao longo dos séculos XVII e XVIII, introduziu compli-

\footnotetext{
33 FONSECA, José Taveira da. A Universidade de Coimbra (1700-1771), op. cit., p. 259.

${ }^{34}$ Sobre o estatuto de "pureza de sangue" ou "limpeza de sangue" em Portugal e na Espanha ver, entre outros: DELACAMPGNE, C. L. Linvention du racisme: Antiquité et Moyen Age. Paris: Fayard, 1983; YERUSHALMI, Y. H. L'antisemitisme racial est-il apparu au XXe siècle? De la limpieza de sangre espagnole au nazisme: continuités et ruptures. Esprit. Paris, março-abril 1993, p. 5-35. Para o estudo do tema no contexto da expansão dos impérios ver, especialmente, NOVINSKY, Anita. Cristãos novos na Bahia. São Paulo: Perspectiva, 1972; MATTOS, Hebe Maria. A escravidão moderna no quadro do Império português: $O$ Antigo Regime em perspectiva atlântica. In: FRAGOSO, João; BICALHO, Fernanda; GOUVEIA, Maria de Fátima (org.). O Antigo Regime nos trópicos: a dinâmica imperial portuguesa (séculos XVI-XVIII). Rio de Janeiro: Civilização Brasileira, 2001; FURTADO, Júnia Ferreira. Chica da Silva e o contratador de diamantes: O outro lado do mito. São Paulo: Companhia das Letras, 2003.

${ }^{35}$ FONSECA, Fernando Taveira da. A Universidade de Coimbra (1700-1771), op. cit., p. 259.

${ }^{36}$ FIGUEIROA-REGO, João de $\mathcal{E}$ OLIVAL, Fernanda. Cor da pele, distinções e cargos: Portugal espaços atlânticos portugueses (séculos XVI a XVIII). Tempo. Rio de Janeiro, UFF, nº 30, janeiro/ junho de 2001, p. 137.
} 
cadores neste demarcador social, extinto oficialmente apenas em 1773, e também interferiu definitivamente noutros demarcadores do Antigo Regime. ${ }^{37}$ Em 1705, a congregação da Faculdade de Medicina de Coimbra insiste em negar a candidatura ao grau de doutor do mulato Antonio de Sousa Falcão, apesar do parecer favorável da Mesa de Consciência e Ordens à primeira consulta feita sobre o assunto. ${ }^{38} \mathrm{O}$ parecer emitido pelo síndico da Universidade merece atenção especial e, por isso, é abaixo reproduzida. Embora utilize o exemplo da exclusão dos judeus batizados da dignidade do doutoramento, a fim de ressaltar a nobreza do grau, o principal argumento do síndico para a negação do privilégio ao mulato Antonio de Sousa Falcão é sua pretensa descendência escrava. Mancha indelével e, para o síndico de Coimbra, justificativa primeira e última para a exclusão dos mulatos e pardos dos altos cargos e privilégios da nobreza. Uma vez que são descendentes

(...) de cativos que correm por comércio e se vendem como bestas, e vindo a ser livres pela manumissão que seus senhores lhes concedem vem a ser Libertinus (...). A estes Libertinus e seus filhos fechou a nobreza a dignidade (sic) as portas para que aspirassem às honras a que só admitem os Cidadãos Romanos. ${ }^{39}$

Seguindo de perto a argumentação do síndico, pode-se concluir que a exclusão da dignidade do doutoramento pautava-se, sobretudo, na ausência de qualidade, ou seja, no reconhecimento de uma origem mecânica em contraposição à descendência nobre. A declaração da congregação em resposta à Mesa ressalta, entretanto, outro argumento, de certa forma também presente no parecer do síndico quando aproxima os diferentes tipos de impureza, e que justificaria igualmente o impedimento: o "defeito da mulatisse (sic)". ${ }^{40}$ Assim, enquanto o parecer do síndico chama a atenção num primeiro plano para o "defeito mecânico" denunciado pela origem de cativos, a declaração da congregação chama a atenção para a incômoda presença, dentro dos mu-

\footnotetext{
37 Silvia Lara analisa com acuidade a historicidade das categorias de cor na América portuguesa ao longo do século XVIII. Segundo a autora, “ainda que se possa identificar nexos evidentes entre cor e condição social, é preciso lembrar que os dispositivos que estabeleciam a relação de identidade entre os dois aspectos não eram empregados de forma mecânica". LARA, Silvia Hunold. Fragmentos setecentistas: Escravidão, cultura e poder na América portuguesa. São Paulo: Companhia das Letras, 2007, p. 146. Sobre a flexibilidade dos requisitos de pureza de sangue na América portuguesa ver, entre outros, RUSSEL-WOOD, A. J. R. Escravos e libertos no Brasil colonial, op. cit., p. 112-19.

${ }^{38}$ FONSECA, Fernando Taveira da. A Universidade de Coimbra (1700-1771), op. cit., p. 258-59.

${ }^{39}$ FONSECA, Fernando Taveira da. A Universidade de Coimbra (1700-1771), op. cit., p. 258.

${ }^{40}$ FONSECA, Fernando Taveira da. A Universidade de Coimbra (1700-1771), op. cit., p. 259.
} 
ros da universidade, de um contingente de mulatos livres originários, na sua maioria, da América portuguesa. Em 1752, os irmãos Felipe de Santiago Brito e Gonçalo Agostinho de Brito, naturais das Minas Gerais, não vão informados para o Desembargo do Paço e, além disso, assinalou-se em seus assentos que eram mulatos. Em 1762, João Rodrigues Lameiro, natural de Sabará, tem uma anotação mais explícita em seu registro: "não tem informação por ser mulato".41 Pesquisas recentes vêm chamando a atenção para as classificações sociais, com particular atenção para a hierarquia da cor e a emergência da ideia de raça na América portuguesa e no reino nos séculos XVII e XVIII. ${ }^{42}$ Assim, por meio de uma documentação variada produzida em diferentes espaços de saber e poder do Antigo Regime português é possível constatar a recorrência, e mesmo a emergência, de algumas das categorias utilizadas pelos doutores de Coimbra. Por exemplo, o "impedimento da mulatice" também foi muito citado nas habilitações do Santo Ofício e das ordens militares. Ao contabilizar os mulatos agraciados com o hábito das ordens militares, sete no total, Dutra observa particularidades quanto à origem geográfica e social dos habilitados. ${ }^{43}$ Chama a atenção o fato de a maioria ser constituída de gente nascida no reino, sendo apenas um nascido no Brasil e outro em Angola. Além disso, tratava-se exclusivamente de filhos de homens brancos ricos e poderosos, por vezes detentores de altos cargos e patentes. Ao contrário das ordens militares, mais condescendentes, se assim podemos dizer, com os mulatos "de qualidade e condição", nas habilitações para familiar do Santo Ofício, o "defeito da mulatice" pareceu se sobrepor às qualidades dos pretendentes, sendo o impedimento "recorrente nas familiaturas do Santo Ofício, entre as décadas de 1680 e 1720". ${ }^{44}$ Assim, no conjunto dos argumentos para o impedimento, parece emergir uma "nova" ideia de raça, agora desvinculada da questão religiosa que demarcava a raça dos judeus e dos mouros - infiéis ou suspeitos de heresia - e pautada na cor da pele, atributos físicos e origem geográfica.

\footnotetext{
${ }^{41}$ FONSECA, Fernando Taveira da. A Universidade de Coimbra (1700-1771), op. cit., p. 261.

${ }^{42}$ Especialmente: DUTRA, Francis. Ser mulato em Portugal nos primórdios da Época Moderna. Tempo, Rio de Janeiro, UFF, $\mathrm{n}^{\circ}$ 30, janeiro/junho de 2011, p. 101-114; RAMINELLI, Ronald. Impedimentos da cor. Mulatos no Brasil e em Portugal, c. 1640-1750. Vária História. Belo Horizonte: UFMG, vol. 28, n. 48, jul/dez 2012, p. 699-723.

${ }^{45}$ DUTRA, Francis. Ser mulato em Portugal nos primórdios da Época Moderna, op. cit., p. 103.

${ }^{44}$ RAMINELLI, Ronald. Impedimentos da cor. Mulatos no Brasil e em Portugal, op. cit., p. 719. Sobre o tema das habilitações para familiares do Santo Ofício na América portuguesa ver: RODRIGUES, Aldair Carlos. Limpos de sangue: Familiares do Santo Ofício, Inquisição e sociedade em Minas colonial. São Paulo: Alameda, 2011.
} 
A anotação "homem preto" no registro de formatura de André do Couto Godinho se relaciona diretamente com outros registros e, sobretudo, com o contexto em comum. Assim, é possível que os doutores de Coimbra, diante de uma realidade americana que atravessava o Atlântico, ou seja, "a emergência de uma população livre de ascendência africana", tivessem que criar novas - e reinventar antigas - categorias para lidar com uma situação que colocava em xeque vários supostos da organização social do Antigo Regime, pilar e sustentáculo do saber e do poder coimbrenses. ${ }^{45}$

Fruto de escolha pessoal ou limitação imposta - provavelmente nunca saberemos -, logo após a formatura, ou talvez em processo paralelo, Godinho candidatou-se ao sacerdócio. Para tanto, foi submetido a um processo de averiguação "de gênere", procedimento indispensável para obtenção de determinados títulos como, por exemplo, a habilitação às ordens militares e cargos públicos mais elevados. A habilitação ao sacerdócio também requeria este tipo de averiguação. ${ }^{46}$

Em contraste com outros processos de habilitação, sobretudo para as três ordens militares, em que a ocultação da origem ou da descendência foi estratégia comum, ${ }^{47}$ o processo de André começava com a apresentação de seus pais Victória do Couto e Pedro Alvares como "pretos legítimos".48 Interessante notar que não há qualquer referência à origem escrava dos pais ou do próprio André. Seria sua ocultação uma estratégia ou um novo elemento a ser considerado na história de André Godinho? Outra linha de investigação a considerar é a identificação dos pais como pretos legítimos e do próprio André como homem preto. Haveria alguma positividade nesta afirmação, considerando que o "defeito da mulatice" e não o da descendência de pretos foi a razão frequentemente explicitada para o impedimento e exclusão dos homens de cor aos altos cargos e títulos? Talvez a história pouco conhecida da presença negra em Portugal (africanos que nunca foram escravos, libertos e escravos) possa trazer alguma luz sobre esta questão.

Por enquanto, as perguntas permanecem sem resposta e apenas a informação de que o candidato ao sacerdócio, sem grandes dificuldades ou argumentos contrários, foi dispensado do defeito da "descendência de pretos"

\footnotetext{
${ }^{45}$ MATTOS, Hebe Maria. A escravidão moderna no quadro do Império português, op. cit., p. 155.

${ }^{46}$ FURTADO, Júnia Ferreira. Chica da Silva e o contratador de diamantes. O outro lado do mito, op. cit., p. 58, 59.

${ }^{47}$ FURTADO, Júnia Ferreira. Chica da Silva e o contratador de diamantes, op. cit.; DUTRA, Francis. Ser mulato em Portugal nos primórdios da Época Moderna, op. cit.

${ }^{48}$ Processos de justificação "de gênere". André do Couto Godinho. AUC.
} 
rev. hist. (São Paulo), n. 173, p. 141-174, jul--dez., 2015 http://dx.doi.org/10.11606/issn.2316-9141.rh.2015.100874
Lucilene Reginaldo

André do Couto Godinho: homem preto, formado em Coimbra, missionário no Congo em fins do século XVIII

para "subir à perfeição sacerdotal". A dispensa tirava do candidato "toda mácula ou nota de inabilidade", não obstante as leis do Império e da Igreja que determinavam o contrário. Nesse sentido, o estigma baseado na ascendência reconhecia brechas para a limpeza do "defeito de origem", certamente no limite de determinados cargos e graus de distinção e de acordo com os jogos de poder em cada localidade do Império, como deixa entrever a rígida postura dos doutores de Coimbra diante dos mulatos candidatos ao doutorado. ${ }^{49}$

Após a formatura e ordenação no ano de 1759, perdi os rastros de Godinho, que reaparece 20 anos mais tarde, em 1779, entre os 22 missionários enviados por d. Maria I para o bispado de Angola. Não obstante, retornando ao texto de sua apresentação às autoridades do bispado de Angola, uma anotação é bastante intrigante quando confrontada com o "desaparecimento" do padre secular formado em Cânones: Godinho gozava "de grande prestígio na Corte"!

Lisboa, na segunda metade do século XVIII, contava com uma notável população de escravizados. Os dados são imprecisos, mas variam sempre entre 5\% e 10\% do total populacional. ${ }^{50}$ Entretanto, a população negra do reino não era composta tão somente por aqueles que viviam na condição de cativos. Havia, assim como na América portuguesa, um contingente populacional de libertos. Algumas abordagens têm sido privilegiadas e recorrentes no tratamento do tema: as péssimas condições de vida do liberto, imerso na pobreza, na indigência e na vida criminosa; os limites das alforrias condicionais; o reduzido número de forros. ${ }^{51} \mathrm{~A}$ ausência de estudos mais sistemáticos sobre as alforrias com base em documentação serial não permite sequer uma quantificação aproximada do número de forros ou uma avaliação de seu impacto na comunidade de escravizados no Portugal moderno. Se Godinho viveu na Corte nas décadas de 1760 e 1770, acompanhou de perto as

\footnotetext{
${ }^{49}$ Sobre a influência dos estatutos de pureza de sangue na formação de um clero africano de nativos, nos séculos XVI e XVII, ver: MARCUSSI, Alexandre Almeida. A formação de um clero africano nativo no Império português nos séculos XVI e XVII. Temporalidades. Belo Horizonte: Programa de Pós-Graduação em História da UFMG, vol. 4, nº 2, ago/dez 2012.

${ }^{50}$ LAHON, Didier. Esclavage et confréries noires au Portugal durant l'Ancien Régime (1441-1830). Tese de doutorado, L'Ehess, Paris, Ecole des Hautes Etudes en Sciences Sociales, 2001; LAHON, Didier. O negro no coração do Império: Uma memória a resgatar - séculos XV-XIX. Lisboa: Secretariado Coordenador dos Programas Multiculturais, Ministério da Educação, 1999, p. 15. Um estudo recente questiona os números apresentados por Lahon, estimando a percentagem de escravos na população de Lisboa, em meados do século XVIII, em 5\%. VENÂNCIO, Renato Pinto. Cativos do reino: A circulação de escravos entre Portugal e Brasil, séculos 18 e 19. São Paulo: Alameda, 2012, p. 89.

${ }^{51}$ Ver: SAUNDERS, A. C. de C. M. História social dos escravos e libertos negros em Portugal (1441-1555). Lisboa: Imprensa Nacional - Casa da Moeda, 1982; LAHON, Didier. O negro no coração do Império, op. cit.
} 
mudanças sociais decorrentes da aplicação e interpretações dos alvarás de 1761 e 1773 que, respectivamente, proibiu o desembarque de escravos no Reino e determinou a libertação dos escravos de $4^{\text {a }}$ geração e também dos nascidos após sua publicação. ${ }^{52}$

Mas havia também aqueles que nunca haviam sido escravos. Nos primeiros séculos de contatos com a África, a exemplo dos primeiros congueses embarcados na frota comandada por Diogo Cão em 1485, vários africanos foram levados a Portugal para serem instruídos na fé, na cultura e nas línguas ocidentais. Alguns desembarcaram em Lisboa como homens livres, eram representantes da corte do mani Congo, embaixadores, parentes da família real. ${ }^{53}$ A política de controle da expansão do catolicismo, levada a cabo pelos soberanos do Congo, investiu na formação de um clero africano. Mesmo após a morte de seu filho bispo, o célebre d. Henrique, o mani Congo d. Afonso I continuou enviando a Lisboa jovens sobrinhos e primos para serem educados no Mosteiro de Santo Elói. ${ }^{54} \mathrm{Na}$ primeira metade do século XIX, os reis do Congo parecem ter dado continuidade à antiga tradição de enviar seus infantes para realizar estudos em Portugal. No ano de 1845, num contexto político delicado e promissor das relações entre Portugal e o Congo, o rei d. Henrique II envia para Coimbra seu filho mais novo - d. Nicolau de Água Rosada e Sardónia - acompanhado do padre congolês Antonio Francisco das Necessidades. ${ }^{55}$

Ao longo dos séculos XVII e XVIII, outros homens e mulheres livres africanos e negros, mulatos e pardos nascidos nas Américas - também desembarcaram e fixaram residência em Lisboa e em outras cidades do reino. $\mathrm{O}$ reconhecimento deste pequeno contingente populacional dentro das fronteiras do reino não distinguia Portugal do restante da Europa, embora seu peso numérico e visibilidade tenham sido destacados por vários visitantes estrangeiros do século XVI ao século XIX, criando uma imagem de singularidade

52 PINHEIRO, Fernanda Aparecida Domingos. Em defesa da liberdade, op. cit., especialmente capítulo 4.

53 BOXER, Charles. A Igreja e a expansão ibérica. Lisboa: Edições 70, 1989, p. 14-15.

${ }^{54}$ BOXER, Charles. A Igreja e a expansão ibérica, op. cit., p. 16. Sobre jovens da nobreza do Reino do Ndongo estudando em conventos metropolitanos e na América portuguesa, ver: SANTOS, Vanicleia Silva. As bolsas de mandinga no espaço atlântico. Tese de doutorado em História, Faculdade de Filosofia Letras e Ciências Humanas, Universidade de São Paulo, 2008, p. 56.

55 Acord du roi du Congo Henrique II (26-06-1845). In: BRÁSIO, Antonio (org.). Angolana. Spiritana monumenta Historica. Série africana. Louvain: Duquesne University Press Pisttsburgh Editions E. Nauwelaerts, 1966, vol. 1, p. 23-24. 
da capital portuguesa. ${ }^{56}$ Estes "olhares estrangeiros" foram responsáveis, em grande parte, pela caracterização exótica da presença negra em Portugal.

Os famosos escravos anões ${ }^{57}$ na Corte da rainha devota, particularmente a personalidade forte de Rosa, a preferida da rainha, chamaram a atenção do viajante inglês Willian Beckford, que esteve em Portugal entre maio e setembro de 1787. Rosa, Ana e Sebastião incomodaram o viajante inglês e certamente não foi por razões humanitárias ou de cunho abolicionista. Para o aristocrata Beckford, a presença dos anões bem vestidos e mimados denunciava o atraso da monarquia portuguesa ao conservar uma prática abandonada e, de certa forma, abominada por outras monarquias europeias do período. ${ }^{58}$ Numa "chave portuguesa", a presença dos anões africanos na Corte dava visibilidade a diversidade e exotismo dos domínios ultramarinos do Reino, tornando-se, ao mesmo tempo, um sinal de distinção para a nobreza. ${ }^{59}$ Ana e Sebastião foram "despachados" de Moçambique, juntamente com outros presentes exóticos, em 1786, ou seja, mais de uma década após a abolição do tráfico em Portugal. Na risca da lei, formalmente não poderiam ser escravos; possivelmente para os naturalistas portugueses, o nanismo e a origem colocavam em dúvida a humanidade/liberdade plena de Ana e Sebastião.

A descrição deste cenário, embora nada informe diretamente sobre o prestígio de Godinho na Corte, de outra parte, faz pensar na origem e estímulos de seus "ardentes desejos de ir à missão no Congo". ${ }^{60}$

\section{A missão de 1779}

O desembarque de Godinho em Luanda ocorreu no dia 4 de dezembro de 1779, coincidindo com a chegada de uma embaixada do rei do Congo pedindo missionários. ${ }^{61}$

Não era a primeira e nem seria a última. Antes desta, outras embaixadas haviam sido enviadas à capital do Reino de Angola por Nepaxi Giacana, também intitulado d. José I de Água Rosada, um quinlaza da região de Qui-

\footnotetext{
${ }^{56}$ LAHON, Didier. Esclavage et confréries noires au Portugal durant l'Ancien Régime (1441-1830), op. cit., p. 56

${ }^{57}$ Os anões da Corte de d. Maria I foram "imortalizados" no quadro Mascarada nupcial [1787 ou 1788], de José Conrado Rosa, pintor português da segunda metade do século XVIII.

${ }^{58}$ DEL PRIORE, Mary. Auberon na Lusitânia. Tempo. Rio de Janeiro: UFF, nº 4, 1997, p. 124-45.

${ }^{59}$ LARA, Silvia Hunold. Fragmentos setecentistas. Escravidão, cultura e poder na América portuguesa, op. cit., p. 232.

${ }^{60}$ Relação dos missionários que chegaram ao Reino de Angola por missionários no ano de 1779, op. cit.

${ }^{61}$ Viagem do Congo do missionário fr. Rafael Castello de Vide, op. cit., p. 23.
} 
bango, eleito rei em 1778, mas ainda não coroado até aquela data. ${ }^{62}$ D. José de Água Rosada não fora reconhecido pelos rivais quimpazu e, num primeiro embate, se vira obrigado a abandonar São Salvador/Mbanza Congo. Por ora, é importante ressaltar que, desde a conversão de Npemba Nzinga, batizado Afonso, e rei do Congo entre os anos de 1506 e 1546, a presença de sacerdotes católicos no rito de entronização era condição indispensável para sua realização. A importância atribuída a esta presença deve ser entendida numa complexa rede de significados que envolvia, ao mesmo tempo, a dimensão sagrada do poder temporal e a legitimidade política do soberano. ${ }^{63}$ Em termos temporais, a adesão ao cristianismo pelos candidatos ao trono do Congo - no caso, afirmada pelo pedido de missionários - foi frequentemente selada com alianças políticas, militares e econômicas.

O atendimento aos insistentes pedidos dos missionários enviados por Nepaxi Giacana/d. José I tinha claros interesses políticos. Nesse sentido, do lado lusitano, o envio de missionários "portugueses" para o Congo poderia contribuir para o estabelecimento de novas relações com seus soberanos seriamente afetadas após a crise provocada pelos confrontos em Ambuíla e no Soyo - objetivando a retomada dos negócios lusos numa região cada vez mais povoada por traficantes ingleses e franceses. ${ }^{64}$ Não resta dúvida de que a embaixada enviada por d. José I interessava de perto às autoridades de Luanda. Também é possível que os mesmos interesses tenham contribuído para a definição da missão e dos missionários que seriam enviados ao Congo.

Quatro missionários foram destacados para a missão no Reino do Congo: o padre doutor André do Couto Godinho, clérigo do hábito de São Pedro; o padre mestre frei Libório da Graça, religioso de São Bento, destinado para vigário geral no Congo; padre mestre frei Rafael de Castello de Vide, religioso reformado de São Francisco da província da Piedade e o padre frei João Gualberto de Miranda, religioso da Terceira Ordem da Penitência de S. Francisco. ${ }^{65}$ Destes, como já observei, apenas o padre Godinho vinha, desde Lisboa, destinado para o Congo. Os demais missionários foram selecionados

\footnotetext{
${ }^{62}$ A facção/clã kinlaza controlava as "terras da rainha", cuja capital era Mukondo no alto do rio Mbrize, o que correspondia aos marquesados de Wembo, Mpemba e parte de Mbamba.

${ }^{63}$ Ver, entre outros: BRÁSIO, António. O problema da eleição e coroação dos reis do Congo. Revista Portuguesa de História. Separata. Coimbra: Instituto de Estudos Históricos Dr. António de Vasconcelos, 1969.

${ }^{64}$ THORNTON, John K. The Kingdom of Kongo: Civil War and transition 1641-1718. Madison/Wisconsin: The University of Wisconsin Press, 1983. Especialmente capítulo 7: Kongo in the Civil Wars.

${ }^{65}$ Breve relação e sumário da viagem que na sua nau Nossa Senhora de 1779..., op. cit.
} 
pelo bispo e pelo governador geral do Reino de Angola de acordo com critérios religiosos e também políticos. Um critério evidente, de natureza religiosa, mas igualmente político, foi a origem portuguesa ou luso-brasileira dos missionários. A escolha do frei Libório da Graça para vigário geral do Congo, por exemplo, feria os antigos privilégios dos capuchinhos que haviam sido durante muito tempo autoridades inquestionáveis nos assuntos religiosos e políticos do Congo. ${ }^{66}$

A primeira missão dos capuchinhos havia chegado ao porto de Mpinda em maio de 1645. Uma parte do grupo permaneceu no Soyo e a outra seguiu para São Salvador. Estes e os futuros missionários capuchinhos nos reinos do Congo e Angola, eram, em sua maioria, italianos e espanhóis. A presença da Ordem dos Frades Menores nesta região da África fez parte de uma estratégia do papado de tomar para si a responsabilidade e o controle das missões católicas, expressa na criação da Propaganda Fide. ${ }^{67} \mathrm{O}$ objetivo final era "retirar" de Portugal e Espanha a prerrogativa de protagonistas na expansão do catolicismo. Portugal, em particular, fazendo valer a instituição do padroado régio, criou numerosos obstáculos à presença de missionários estrangeiros em suas conquistas.

\footnotetext{
${ }^{66}$ Embora a jurisdição eclesiástica da diocese de Angola e Congo só tenha sido transferida para a capital do Reino de Angola em 1676, a transferência efetiva da residência episcopal de São Salvador para Luanda data do ano de 1628. Mas tudo indica que foi tão somente no tempo do bispo d. Luís Simões Brandão (1701-1719) que a mais elevada autoridade religiosa católica no Congo passou a ser desempenhada por um vigário geral. SOUSA, d. Gabriel de. Fr. Libório da Graça - missionário beneditino em Angola, no século XVIII. Boletim da Academia Internacional da Cultura Portuguesa. Separata, $\mathrm{n}^{0}$ 5, 1969, p. 147.

${ }^{67}$ Ver: GRAY, Richard. Black Christians and white missionaries. New Haven e Londres: Yale University Press, 1990, especialmente capítulo 2; BOXER, Charles R. O império marítimo português 1415-1825. São Paulo: Companhia das Letras, 2002, especialmente capítulo 10.
} 
rev. hist. (São Paulo), n. 173, p. 141-174, jul.-dez., 2015 http://dx.doi.org/10.11606/issn.2316-9141.rh.2015.100874
Lucilene Reginaldo

André do Couto Godinho: homem preto, formado em Coimbra, missionário no Congo em fins do século XVIII

\section{Imagem 3}

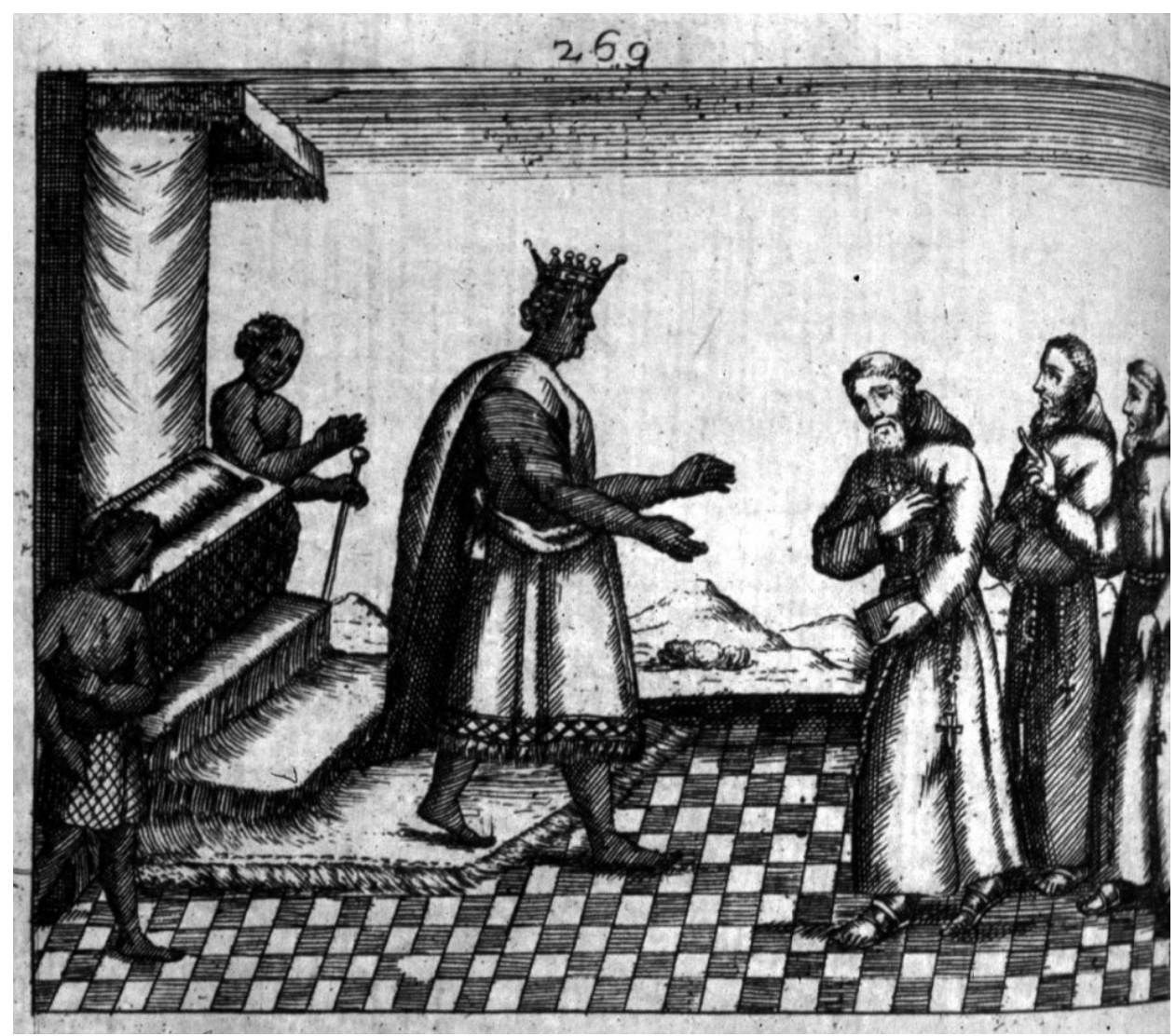

Missão Capuchinha no Reino do Congo, gravura do século XVII. Giovanni António Cavazzi de Montecuccolo,1687 Descrição histórica dos três Reinos do Congo, Matamba e Angola

Ao contrário de seus antecessores, os papas seiscentistas decidiram trazer as missões ultramarinas para o controle de Roma. Nessa altura, o papado passou a questionar os privilégios por ele mesmo concedidos ao padroado português e ao patronato espanhol por considerá-los então "inconvenientes e subversivos para a autoridade papal". Praticamente nada pode ser feito contra o patronato dos reis de Castela, respaldado pelo bom êxito da missionação na América. Em relação a Portugal, entretanto, enfraquecido após a derrocada de seu monopólio na África e Ásia, em decorrência das investidas vitoriosas de ingleses e holandeses, o papado agiu de forma enérgica.

O papa Inocêncio X insistia, portanto, como haviam feito seus três predecessores imediatos, na ideia de que o monopólio missionário português não era eficaz, estava 
ultrapassado e que missionários de outros países europeus deveriam ser autorizados a partir para a África e para a Ásia sem nenhuma interferência dos portugueses. ${ }^{68}$

Os monarcas de Bragança reagiram com energia na defesa dos seus direitos de padroado. Dentre outros episódios desta batalha política destaca-se a recusa do papado em reconhecer a independência e consagrar bispos portugueses entre 1640-1668. A Propaganda Fide, criada justamente neste período de grandes embates entre Roma e a Coroa portuguesa, durante séculos esteve no centro das tensões que envolveram o papado e os representantes do padroado português nas conquistas. ${ }^{69}$

A política pombalina buscou minar a influência dos capuchinhos nos assuntos religiosos e políticos das conquistas de Portugal. Durante o governo do marquês de Pombal, a entrada de missionários capuchinhos em Angola e no Congo foi rigidamente controlada. Neste último reino, os capuchos foram obrigados a abandonar nove hospícios ou missões, uma após a outra, de modo que, entre as décadas de 1760 e 1790, nenhum capuchinho entrou nas terras do Congo. ${ }^{70}$ Apesar da retomada do incentivo às atividades missionárias no reinado de d. Maria I, os barbadinhos italianos continuaram encontrando dificuldades para retomar suas atividades missionárias no bispado de Angola e Congo. A resistência era oriunda tanto das autoridades leigas quanto das autoridades religiosas. Enquanto os primeiros pareciam temer o perigo estrangeiro corporificado pelos missionários, especialmente no Congo, para as autoridades eclesiásticas, a autonomia religiosa desses missionários não era conduta de boa reputação. ${ }^{71}$

De outra parte, as mesmas autoridades eclesiásticas instaladas na capital do Reino de Angola enfrentavam sérios problemas para a organização do culto católico no decorrer do século XVIII. No início do século, Luanda sede do bispado de Angola e Congo - possuía apenas duas freguesias ( Nossa Senhora da Conceição e Nossa Senhora dos Remédios), cerca de uma dezena de modestos templos e quatro casas religiosas. Falta de missionários, templos em ruína e a duvidosa honradez do clero eram temas frequentes nas corres-

\footnotetext{
${ }^{68}$ BOXER. O império marítimo português, 1415-1825, op. cit., p. 247.

${ }^{69}$ BOXER. O império marítimo português, op. cit., p. 248-249.

${ }^{70}$ JADIN, Louis. Les missions du Congo à la fin du XVIIIe siècle. In: CONGRESSO INTERNACIONAL DE HISTÓRIA DOS DESCOBRIMENTOS, vol. 5, parte II, 1961. Actas. Comissão Executiva das Comemorações do V centenário da morte do infante d. Henrique. Lisboa: CIHD, 1961, p. 207-231.

${ }^{71}$ JADIN, Louis. Les missions du Congo à la fin du XVIIIe siècle, op. cit., p. 3.
} 
rev. hist. (São Paulo), n. 173, p. 141-174, jul.-dez., 2015 http://dx.doi.org/10.11606/issn.2316-9141.rh.2015.100874
Lucilene Reginaldo

André do Couto Godinho: homem preto, formado em Coimbra, missionário no Congo em fins do século XVIII

pondências entre as autoridades eclesiásticas e o Conselho Ultramarino. ${ }^{72}$ Em 1732, o bispo de Angola, frei Antonio do Desterro, pede providências para remediar a falta de cadeia para clérigos delinquentes e aproveita a ocasião para também solicitar provimentos para a igreja da Sé que se encontrava em "miserável estado de paramentos".73 A carência de religiosos se agravara no período pombalino com a expulsão dos jesuítas e o controle da entrada dos missionários capuchinhos. Dessa forma, reclames dessa natureza, com a mesma frequência e dramaticidade, persistem até o final do século XVIII.

Ao chegar em Luanda "com ardentes desejos de ir a missão no Congo", André do Couto Godinho deparou-se com uma grave crise das atividades missionárias no bispado de Angola e Congo e particularmente no antigo Reino do Congo. A missão de 1779 foi, de certa forma, uma resposta das autoridades portuguesas aos muitos reclames enviados à Corte.

As crescentes tensões e conflitos envolvendo os interesses portugueses no Congo, desde a segunda metade do século XV, levaram à concentração dos esforços de missionação em Angola, sobretudo em Luanda, centro político e administrativo da nova conquista. ${ }^{74}$ Embora o Congo continuasse formalmente como sede do bispado, o prelado responsável pelo governo da diocese de Congo e Angola desde 1628 passara a residir em Luanda. Mesmo assim, a jurisdição eclesiástica da diocese só foi transferida para capital do Reino de Angola em 1676. ${ }^{75}$

72 Ofício do governador de Angola [Rodrigues de Meneses] ao Conselho Ultramarino sobre a falta de missionário no Reino, 2 de março de 1735. AHU, Angola, cx. 28, doc. 3.

${ }^{73}$ Ofício do bispo de Angola ao Conselho Ultramarino acerca da falta de cadeia para os clérigos delinquentes, 23 de fevereiro de 1739. Ofício do bispo de Angola ao Conselho Ultramarino sobre o miserável estado em que se encontravam os paramentos da Sé, 23 de fevereiro de 1739. AHU, Angola, cx. 31, docs. 7, 6.

${ }^{74}$ A vitória em Ambuíla revelou e ao mesmo tempo coroou os novos rumos da política lusa com relação à África central. Para Alencastro, essa nova política era incompatível com a presença de um soberano africano cristão reinando de forma independente e fazendo livre comércio com europeus diversos. Assim, "de certo modo, a batalha representava o choque das alternativas que se apresentavam à expansão portuguesa, a pilhagem e o comércio, a conquista militar e a política de governo indireto, Angola e Congo, Brasil e Índia". ALENCASTRO, Luiz Felipe de. O trato dos viventes, op. cit., p. 293.

${ }^{75}$ CUNHA, Manuel Alves da. Notas para uma cronologia eclesiástica e missionária do Congo e Angola (1491-1944). Arquivos de Angola. Luanda, $2^{\mathrm{a}}$ serie, vol. II, 1944, p. 46, 53. Desde então, a estrutura eclesiástica do bispado de Angola e Congo passou a funcionar na cidade-porto de Luanda, centro político e administrativo da conquista e o mais importante porto do tráfico de escravos do Atlântico. Após a restauração portuguesa em 1648, em decorrência da intensificação do comércio de escravos para a América, Luanda cresceu vertiginosamente, tornando-se "o maior porto negreiro do Atlântico". Ver, entre outros: ALENCASTRO. O trato dos viventes, op. cit.; 
rev. hist. (São Paulo), n. 173, p. 141-174, jul.-dez., 2015 http://dx.doi.org/10.11606/issn.2316-9141.rh.2015.100874
Lucilene Reginaldo

André do Couto Godinho: homem preto, formado em Coimbra, missionário no Congo em fins do século XVIII

Após a batalha de Ambuíla em 1665 e a consequente fragmentação do antigo Reino de Congo, o trabalho dos missionários tornou-se mais difícil naquela região, especialmente em razão da guerra civil e das disputas políticas que tornavam os deslocamentos muito perigosos. Entre os anos de 1665 e 1695, foram catorze os pretendentes ao trono do Congo. ${ }^{76}$ A disputa pela posição de mani Congo não foi propriamente uma inovação na política do século XVII. Ao contrário, era algo presente na lógica de transmissão do poder. O mani Congo era eleito pelos chefes dos clãs mais influentes; entretanto, o direito à sucessão estava associado ao parentesco matrilinear. ${ }^{77}$ Portanto, candidatos a suceder o rei falecido seriam seus irmãos e sobrinhos. Com isso, as rivalidades entre os candidatos e o difícil processo de construção de legitimidade foram uma constante. Assim, a complexa organização política do Reino do Congo no século XVIII resultou, em parte, das antigas estruturas de equilíbrio de poder entre as províncias e, por outra parte, da emergência dos novos grupos políticos e econômicos desde os primeiros contatos com os europeus. A unidade política do reino - talvez não aquela vislumbrada pelos primeiros europeus que conheceram o Congo - foi mortalmente abalada no século XVII. Desde então, a crise de legitimidade do poder central conviveu com paradoxais intentos de reunificação do reino.

As lutas entre facções políticas atravessaram todo o século XVIII, embora a guerra civil tenha terminado com a restauração do reino por Pedro IV (1709-1716) e o estabelecimento de um compromisso que permitia a alternância do poder entre as duas principais facções políticas (Quimpanzu e Quinlaza). O clima de violência e instabilidade política tornou praticamente inviável a presença de missionários no Congo, especialmente após a década de $1760 .{ }^{78} \mathrm{Na}$ verdade, o conflito político e militar ganhou novas configura-

\footnotetext{
MILLER, Joseph. Way of death. Merchant capitalism and the Angolan slave trade, 1730-1830. Wisconsin: University of Wisconsin Press, 1988.

${ }^{76}$ SILVA, Chantal Luís.Jogoseinteressedopodernos reinos doCongoe Angola nosséculosXVIaXVIII.Disponível em: http://cvc.instituto-camoes.pt/eaar/coloquio/comunicacoes/chantal_luis_silva.pdf.

77 Sobre as estruturas e transformações históricas dos padrões de descendência na África central ver, entre outros: MacGAFFEY, Wyatt. Lineage, structure, marriage and family amongst the Central Bantu. Journal of African History. Cambridge: Cambridge University Press, vol. 24, 1983, p. 173-187; HILTON, Anne. Family and kinship among the Kongo South of the Zaire river from the sixteenth to the nineteenth centuries. Journal of African History. Cambridge University Press, vol. 24, 1983, p. 189-206.

${ }^{78}$ Dessa forma, em contrapartida à abundância de registros escritos por religiosos ao longo do século XVII, o século seguinte deixou poucos documentos sobre a vida social e política do Reino do Congo. Os capuchinhos Angelo Maria de Polinago e Querubino de Savona visitaram o
} 
ções ao longo do século XVIII em razão, sobretudo, das flutuações na exportação de escravos para mercadores franceses e ingleses pelos portos ao norte da costa de Loango. ${ }^{79}$

Embora diretamente comprometidos com os assuntos da religião, os missionários enviados para o Reino do Congo também se vincularam ao contexto político e econômico acima esboçado. Além de missionários, os religiosos enviados ao Congo receberam instruções precisas para apoiar o pretendente ao trono "amigo dos portugueses" e, ao mesmo tempo, intermediar os interesses dos comerciantes portugueses no Congo. ${ }^{80}$

Definido o grupo, foi preciso aguardar algum tempo, ou melhor, "o tempo mais apto para sair em missão", a estação mais fresca do ano. Na estada em Luanda, os missionários destacados para a missão no Congo puderam ser bem instruídos nos assuntos políticos que deveriam intermediar e logo souberam que o governador geral "tinha grande empenho nesta Missão que fôssemos bem preparados". ${ }^{81}$ Godinho e seus companheiros de missão permaneceram oito meses em Luanda até, finalmente, no dia 8 de agosto de 1780, tomarem o rumo do Reino do Congo numa embarcação que partiu da barra do rio Dande. Chegaram à barra no dia seguinte, sendo recebidos pelo capitão-mor do distrito. A partir daí, seguiram caminho por terra, acompanhados de uma comitiva de mais de 200 carregadores e um distinto "preto calçado (...) condutor e intérprete dos missionários pelas terras do Congo". ${ }^{82}$

\footnotetext{
Congo, respectivamente, em 1733 e entre 1760 e 1768, e puderam assim testemunhar e registrar episódios importantes das guerras civis e da nova conjuntura do tráfico de escravos. Quase duas décadas depois, Castello de Vide registrou detalhes da sua experiência, mesclada com a narrativa de eventos importantes da história política do Congo. Na última década do século XVIII, o capuchinho Raimundo de Diacomano deixou um registro mais conciso sobre episódios igualmente importantes da história do reino. Sobre os relatos produzidos pelos missionários capuchinhos no século XVII ver: ALMEIDA, Carlos. A natureza africana na obra de Giovanni António Cavazzi - um discurso sobre o homem. Disponível em: http://cvc.instituto-camoes.pt/eaar/coloquio/comunicacoes/carlos_almeide.pdf; GRAY, Richard. Black Christians and white missionaries, op. cit., 1990

${ }^{79}$ THORNTON, J. K. As guerras civis no Congo e o tráfico de escravos: a história e a demografia de 1718- 1844 revisitadas. Estudos Afro-Asiáticos. Rio de Janeiro: Centro de Estudos Afro-Asiáticos da Universidade Cândido Mendes, nº 32, 1997, p. 55-74.

${ }^{80}$ Carta do bispo de Angola [frei Luís da Anunciação] ao vigário geral do Congo [frei Rafael Castello de Vide]. Luanda, 17-2-1784. AHU, Angola, cx. 68, doc. 32; Carta de Rafael Castello de Vide e André do Couto Godinho para bispo de Angola [frei Luís da Anunciação]. São Salvador do Reino do Congo, 29-03-1784. AHU, cx. 68, doc. 61.

${ }^{81}$ Viagem do Congo do missionário fr. Rafael Castello de Vide, op. cit., p. 25.

${ }^{82}$ Viagem do Congo do missionário fr. Rafael Castello de Vide, op. cit., p. 28.
} 
rev. hist. (São Paulo), n. 173, p. 141-174, jul.-dez., 2015 http://dx.doi.org/10.11606/issn.2316-9141.rh.2015.100874
Lucilene Reginaldo

André do Couto Godinho: homem preto, formado em Coimbra, missionário no Congo em fins do século XVIII

Mais uma vez, o deslocamento, agora por terra, exigiu um vigor físico fora do alcance de alguns dos missionários. Na verdade, a malária, a doença do bicho, a sarna, a febre amarela e outros inimigos mortais dos antigos missionários de África não pouparam nenhum dos quatro missionários. ${ }^{83}$ Godinho e Castello de Vide sobreviveram, apesar das muitas sequelas. O padre Libório da Graça faleceu no dia 6 de outubro de 1780, ainda no início da viagem; o padre João Gualberto de Miranda morreu dois anos depois, em 1783, também nas terras do Congo. Após a morte do padre Libório, Rafael Castello de Vide foi nomeado vigário geral no Congo. ${ }^{84}$

Depois do falecimento de João Gualberto, Godinho e Castello de Vide foram, por vários anos, os principais pilares dos interesses religiosos e econômicos da Coroa portuguesa e de Luanda nas terras do Congo. Devemos especialmente ao futuro bispo de São Tomé a narrativa mais detalhada das viagens e missão do Congo. ${ }^{85}$ Este deixou para a posteridade, entre outros registros e correspondências esparsas, um conjunto precioso de escritos sobre os anos vividos no Reino do Congo. ${ }^{86}$ Trata-se de quatro longas relações destinadas ao seu provincial em Portugal: a primeira datada de 16 de julho

${ }^{85}$ BRÁSIO, António. O inimigo dos antigos colonos e missionários de África. História e missiologia: inéditos e esparsos. Luanda: Instituto de Investigação Científica de Angola, 1973.

${ }^{84}$ Mais detalhes sobre a biografia dos missionários falecidos no Congo podem ser encontrados em dois opúsculos a saber: SOUSA, d. Gabriel de. Frei Libório da Graça: missionário beneditino em Angola, no século XVIII, op. cit. e SILVEIRA, Luís. Um missionário português no Congo nos fins do século XVIII. Lisboa: Agência Geral das Colônias, 1943.

${ }^{85}$ Em mais de um trecho da narrativa de Castello de Vide, bem como em outras fontes do final do século XIX, menciona-se a existência de cartas e escritos redigidos pelo padre doutor André do Couto Godinho. Infelizmente, até o presente momento, não localizei nenhum. Num relatório de 1858, o tenente Zacharias da Cruz Silva informa que, numa povoação denominada Quinganga, a poucos dias de distância do rio Mbrize, encontrou: “Uma certidão, incompleta, passada pelo Padre missionário André do Couto Godinho, em 30 de junho de 1778, e tendo uma nota de outro Padre, José Raimundo, capuchinho, missionário apostólico da sagrada congregação, lançada em 9 de junho de 1793. Outra carta, sem data, do mesmo André do Couto Godinho, que nela se intitula presbítero do hábito de S. Pedro, bacharel em cânones formado pela universidade de Coimbra, e missionário apostólico no reino do Congo". Extrato de um relatório do chefe do concelho de d. Pedro $5 .^{\circ}$, o tenente Zacharias da Silva Cruz, sobre a sua viagem a S. Salvador do Congo. Disponível em: www.arlindo-correia.com//020907.html.

${ }^{86}$ As quatro relações reunidas numa brochura constituem o manuscrito ${ }^{0} 396$, série vermelha da Academia das Ciências de Lisboa. Em 1894, o manuscrito foi traduzido para o italiano por Marcelino da Civezza e foi incluso no volume sétimo, tomo 4, da Storia universale delle missioni francescane, composta por 11 volumes, obtendo, de outra parte, um lugar de destaque na história da Ordem dos Frades Menores Franciscanos. Recentemente, o documento foi transcrito na íntegra, com a grafia modernizada, pelo padre Arlindo Correa e está disponível em: www. arlindo-correia.com/161007.html. Acesso em: 20/03/2011. 
rev. hist. (São Paulo), n. 173, p. 141-174, jul.-dez., 2015 http://dx.doi.org/10.11606/issn.2316-9141.rh.2015.100874
Lucilene Reginaldo

André do Couto Godinho: homem preto, formado em Coimbra, missionário no Congo em fins do século XVIII

de 1781; a segunda, de 25 de setembro de 1782; a terceira, de 27 de agosto de 1783; e a quarta e última, de 27 de novembro de $1787 .{ }^{87}$ A preservação dos escritos de Castello de Vide explica-se, em grande parte, pela trajetória do religioso, tanto quanto pela importância de seus relatos para a história dos frades menores. Rafael Castello de Vide, franciscano reformado da Estreita Observância, era padre mestre no Convento de N. S. da Consolação do Bosque de Borba, província da Piedade, no Alentejo. ${ }^{88}$ Após sua experiência como vigário geral no Congo, em 1794, foi nomeado bispo de São Tomé e Príncipe, tomando posse do cargo em 17 de agosto de 1797. Num período, entre os anos de 1798 e 1799, foi também governador interino das ilhas de São Tomé e Príncipe. ${ }^{89}$ Falecido em São Tomé a 17 de janeiro de 1800, aos 52 anos, deixou uma série de cartas, hoje publicadas.90

Nas longas cartas escritas por Castello de Vide abundam detalhadas descrições sobre os caminhos, as populações e o "martírio" dos missionários. Durante o longo e difícil trajeto entre a barra do rio Dande e Mbanza Congo/

\footnotetext{
${ }^{87}$ É possível que o longo intervalo entre a terceira e última correspondência tenha sido em razão do estado de saúde de Castello de Vide. No relato de 1783, o missionário reclama insistentemente de uma sarna, por ele denominada "minha sarna", que lhe parecia incurável ao longo dos anos. Na breve correspondência de 1787, sua condição de saúde parece muito mais precária e dessa maneira é descrita por Castello de Vide "Eu vou vivendo com uma moléstia terrível de cursos, lançando muito sangue por baixo, além de moléstia do estômago, e outras (...)".

${ }^{88}$ Os frades da Estreita Observância se distinguiram dos frades conventuais (ou claustrais) ao promoverem reformas espirituais caracterizadas pela observância integral da regra de São Francisco. Assim, pregavam a disciplina mais austera, exaltação da pobreza evangélica, defesa da simplicidade das residências dos frades e a pregação popular. Eram conhecidos na Espanha por "descalços" ou alcantarinos, pela influência que tiveram de São Pedro de Alcântara. Em Portugal, passaram a ser conhecidos por "capuchos" (devido ao feitio pontiagudo do capucho), o que não tem nada a ver com a Ordem dos Frades Capuchinhos. "Em Portugal, os franciscanos da Regular Observância estiveram reunidos na Província de Portugal (1517), Algarves (1532) e São João Evangelista (1639), enquanto as províncias da mais Estreita Observância eram: Província da Piedade (1517 e 1518), da Arrábida (1560), de Santo Antônio, estabelecida em 1568. Em 1673, a Província da Piedade subdividiu-se com a formação da Província da Soledade e, em 1705, foi fundada a da Conceição". FARIA, Patrícia Souza. Literatura espiritual e história dos franciscanos no oriente português: a escrita de Jacinto de Deus, um homem nascido na cidade do nome de Deus de Macau, p. 223. Disponível em: http://www.editoraufff.com.br/ revista/index.php/locus/article/viewFile/1519/1062. Acesso em: 14/02/2014.

${ }^{89}$ BETHENCOURT, Francisco \& CHAUDHURI, Kirti. História da expansão portuguesa (O Brasil na balança do Império, 1697-1808). Navarra, Espanha: Temas e Debates, 1998, p. 323.

${ }^{90}$ Frei Rafael Castello de Vide. Instrução pastoral de 7 de dezembro de 1797 do bispo de São Tomé e Príncipe às suas ovelhas. Manuscritos. Biblioteca Nacional de Lisboa, cx. 172, doc. 264; COELHO, Laranjo, P. M. O bispo missionário fr. Rafael de Castelo de Vide: alguns subsídios inéditos para a história da sua notável ação espiritual e temporal em Angola, Congo, ilhas de S. Tomé e Príncipe. Memórias da Academia de Ciência de Lisboa. Separata [s.n.], 1959.
} 
São Salvador, os missionários tiveram contato com populações, pequenos e grandes senhores do Congo, bem como com a complexa organização geopolítica do reino. ${ }^{91}$

A insegurança e a instabilidade política nas terras do Congo é vivenciada diariamente pelos missionários. À medida que foram adentrando as terras do Congo, os religiosos puderam reconhecer dois níveis do conflito político-militar: os conflitos localizados e as grandes ações de combate. ${ }^{2}$

Ao entrarem no ducado de Mbamba, importante território político do Congo, conheceram de perto grupos armados que saqueavam e aterrorizavam os viajantes e populações ao longo das estradas. Embora se apresentassem muitas vezes vinculados a partidarismos políticos, o interesse primeiro desses bandos armados era, frequentemente, a captura de escravos e/ou de mercadorias para o tráfico atlântico. A insegurança provocada por esses grupos entre as populações do Congo, ainda que mal compreendida pelos missionários, era motivo de preocupação e enfrentamentos. Na prolongada e custosa viagem rumo à Corte, os missionários enfrentaram, mais de uma vez, problemas envolvendo os carregadores, responsáveis pelo transporte das cargas, bagagens e também dos missionários, especialmente quando já se encontravam esgotados pela longa jornada. "Nos determinamos, ainda que todos com pouca saúde, a seguir a viagem, o que custou bem por causa dos carregadores principiarem logo a mostrar a sua rebeldia e fugirem para adiante, sem nos quererem levar".93

É provável que a fuga dos carregadores tivesse relação direta com o medo da escravização que rondava aquelas populações. Assim, quanto mais distante de sua aldeia ou banza, mais arriscado transitar por caminhos e sertões. Desse modo, o que pareceu aos exaustos missionários uma manifestação de desleixo ou pouco apreço pela vida dos religiosos, poderia ser um ato de preservação da própria liberdade para muitos carregadores.

As disputas internas no Reino do Congo eram conhecidas pelos missionários desde o início da jornada. Em carta ao seu superior, Castello de Vide

\footnotetext{
${ }^{91}$ Sobre as diversas definições e diferenças políticas e geopolíticas das localidades que compunham o reino do Congo ver: SAPEDE, Thiago Clemêncio. Muana Congo, Muana Nzambi Ampungu: poder e catolicismo no reino do Congo pós-emancipação (1769-1795). Dissertação de mestrado em História, Faculdade de Filosofia e Ciências Humanas, Universidade de São Paulo, 2012, especialmente capítulo 4.

92 BROADHEAD, Susan Herlin. Beyond decline: the Kingdom of the Kongo in the eighteenth and nineteenth centuries. The International Journal of African Historical Studies. Boston: Boston University, vol. $12, n^{\circ} 4,1979$, p. 615-650.

${ }^{95}$ Viagem do Congo do missionário fr. Rafael Castello de Vide, op. cit., p. 60.
} 
apresenta uma pequena notícia sobre o Reino do Congo na qual explicita o conflito político como tema central. "É um Reino muito antigo, dilatado, e um grande Império, ainda que hoje se acha dividido entre muitos grandes levantados, que se separaram do Rei, mas sempre se reconhecem seus vassalos".94

Nas terras de Mpembe, muito próximo da corte, os missionários foram recebidos pelo infante Afonso de Leão, irmão do rei d. José. Na Mbanza de Afonso de Leão, receberam uma carta enviada pelo líder dos rebeldes que ocupavam Mbanza Congo "em que dizia ser ele o Regente do Reino, que aqueles de cuja parte nos achávamos eram injustos agressores, e que era vivo um Dom Pedro Quinto Rei do Congo verdadeiro".95 Castello de Vide registra sua dúvida sobre a legitimidade de d. José I, despertada após este contato, ainda que a decisão tenha sido a continuidade do apoio ao mesmo rei, como determinavam as orientações que traziam de Luanda.

No dia 30 de junho de 1781, depois de quase onze meses de viagem, os três missionários chegaram à presença de d. José I de Água Rosada que, próximo a São Salvador/Mbanza Kongo, se preparava para ocupar a capital do reino com um exército de cerca de 30.000 homens. Mbanza Congo, embora em ruínas, era um símbolo político importante para o rei eleito. Sua retomada das mãos dos partidários do falecido d. Pedro V, que inconformados com a escolha do novo rei exigiam novo pleito, seria um passo importante para a conquista de sua legitimidade política. Assim, a espera pela chegada dos missionários para o início da ocupação de São Salvador pode ter sido estratégica em termos simbólicos e políticos. André do Couto Godinho e Castello de Vide acompanharam o exército de d. José I na retomada de São Salvador/Mbanza Congo na esperança de que o restabelecimento do reino seria também o restabelecimento da religião católica e dos interesses da Coroa portuguesa. ${ }^{96}$ D. José I, de sua parte, ficou muito satisfeito com a presença dos missionários ao seu lado, pois pode enfim ser coroado em 15 de dezembro de 1781.

\section{Clérigo preto, missionário, embaixador}

Godinho desembarcou em Luanda com cerca de 59 anos; era o mais velho dos 22 religiosos enviados para o bispado de Angola e Congo, podendo

\footnotetext{
${ }_{94}$ Viagem do Congo do missionário fr. Rafael Castello de Vide, op. cit., p. 25-26.

${ }^{95}$ Viagem do Congo do missionário fr. Rafael Castello de Vide, op. cit., p. 79.

${ }^{96}$ Frei João Gualberto não acompanhou os missionários que foram ao encontro do mani Congo, ficando em recuperação num povoado próximo a Mbanza Congo.
} 
rev. hist. (São Paulo), n. 173, p. 141-174, jul.-dez., 2015 http://dx.doi.org/10.11606/issn.2316-9141.rh.2015.100874
Lucilene Reginaldo

André do Couto Godinho: homem preto, formado em Coimbra, missionário no Congo em fins do século XVIII

ser considerado um homem em idade avançada para o árduo trabalho missionário nas terras africanas. Sua decisão de embarcar para Angola pode ter tido alguma relação com os limites impostos à ascensão social de um homem livre de cor nas terras do reino. Formado em Cânones, impedido de concorrer aos cargos no Desembargo do Paço, "optou" pela carreira eclesiástica dentro dos limites do título de bacharel - mas, ainda assim, chegou a gozar de prestígio na Corte. De outra parte, as narrativas de sua experiência como missionário no Reino do Congo são reveladoras de uma energia extraordinária, que faz pensar não apenas nas limitações impostas, mas também em escolhas mais ousadas. Durante a primeira viagem para São Salvador, Godinho foi acometido de grave enfermidade - possivelmente malária -, sobrevivendo para realizar seu "ardente desejo de ir à missão no Congo", e protagonizou em várias ocasiões ações de destaque no âmbito religioso e político.

Castello de Vide apresenta e manifesta seu apreço pelo padre Godinho em diferentes ocasiões. Numa delas, escreve: "clérigo preto mas de alma bem branca pelas suas virtudes". Os debates teológicos no tocante à legitimidade da escravidão africana certamente informaram esta interpretação de Castello de Vide sobre Godinho. O entendimento de que a cor escura era uma mácula - fruto do pecado original ou da maldição de Cam,$-{ }^{97}$ mas possível de superação por meio da conversão e da prática das virtudes cristãs, teve ilustres defensores na Época Moderna, entre eles, e talvez o mais brilhante de todos, o padre Antonio Vieira. Em seu famoso sermão do Rosário defendeu com veemência a unidade da natureza humana que se sobrepõe ao acidente da cor, sendo, desse modo, a escravidão não uma decorrência natural, mas resultado do delito, da força, da guerra justa ou injusta. ${ }^{98}$ Se de alguma forma Castello de Vide chegou a comungar desses argumentos teológicos, uma convivência mais fraterna com o padre Godinho pode realmente ter acontecido, como sugere o relato do missionário franciscano em outra passagem: "Com este Padre companheiro, e bom sacerdote, eu vivo com muita

\footnotetext{
${ }^{97} \mathrm{O}$ principal argumento discursivo da cristandade moderna para a justificativa da escravidão africana foi a maldição de Cam. Segundo Suess: “No livro do Gênese a escravidão é descrita como maldição que caiu sobre Cam e fatalmente também sobre seu filho Canaã e sua descendência (Gn., 9, 18ss). Canaã, filho de Cam que foi amaldiçoado por Noé, haveria de se tornar o último dos escravos de seus irmãos. Portanto, uma parcela nova da humanidade que saiu do dilúvio já atraiu a maldição fatal e irreversível da escravidão". SUESS, Paulo (ed.). Etíope resgatado, empenhado, sustentado, corrigido, instruído e libertado. Discurso sobre a libertação dos escravos no Brasil de 1758. Petrópolis: Vozes, 1992, p. XXVIII

${ }^{98}$ RAMINELLI, Ronald. Impedimentos da cor, op. cit., p. 709.
} 
satisfação; entre nós há uma sincera amizade; entre nós, não tem havido jamais alguma diferença".99

A confiança e a parceria foram vitais para a sobrevivência e o trabalho dos missionários no Reino do Congo entre os anos de 1781 a 1787. Desse modo, emergem da narrativa de Castello de Vide episódios marcantes da experiência de seu companheiro de missão religiosa e embaixada política.

Entre os vários episódios de protagonismo, a iniciativa de Godinho de ir ao encontro do rei d. José I nas imediações de São Salvador, ganha destaque especial. Após dez meses de viagem e sentindo-se prisioneiro do marquês de Mpemba, d. Afonso de Leão - irmão de d. José I e rei do Congo coroado em 1784, após a morte do irmão -, Godinho lidera a iniciativa dos missionários de levar a cabo o objetivo primeiro da missão, chegando à presença do rei do Congo para entregar-lhe presentes e propostas de amizade. A arrojada ação resultou positivamente e, em consequência, Castello de Vide e João Gualberto foram levados por uma escolta à presença do rei "aonde se achava (...) o nosso padre companheiro, que havia adiantado, Padre Dr. André". Apesar da idade e das várias moléstias, é possível que Godinho estivesse em melhores condições físicas que seus companheiros e, por isso, capaz de suportar os vários dias de caminhada que separavam a Mbanza de Afonso de Leão e o acampamento do rei nas proximidades de Mbanza Congo. Sua disposição para os longos deslocamentos e para as negociações políticas também foi atestada em outras ocasiões.

No dia 28 de setembro de 1781, o exército de d. José I sitiou e, finalmente, ocupou São Salvador, eliminando e aprisionando os antigos ocupantes e adversários. Dois dias após a ocupação, em 30 de setembro, Godinho e Castello de Vide, muito impressionados com a mortandade resultante da investida militar, entravam em São Salvador na companhia de d. José I. O trabalho dos missionários, a partir de então, ficava mais intenso, abrangendo novos territórios - inclusive dos inimigos do mani Congo - e também contemplando interesses do soberano de Mbanza Congo. Assim, enquanto Castello de Vide permanece na Corte, por solicitação do próprio d. José, Godinho vai missionar nas terras de origem dos quinlaza. ${ }^{100}$

Godinho e Castello de Vide assistem, no ano de 1784, à morte do mani Congo Nepaxi Giacana, podendo o vigário geral coroar o novo rei Afonso $\mathrm{V}$ alguns meses após o falecimento do antecessor. É possível que, em con-

\footnotetext{
${ }^{99}$ Viagem do Congo do missionário fr. Rafael Castello de Vide, op. cit., p. 225. ${ }^{100}$ Viagem do Congo do missionário fr. Rafael Castello de Vide, op. cit., p. 128.
} 
sequência deste novo cenário político, em março de 1785, Castello de Vide, acompanhado de um embaixador do mani Congo, marchava por quase dois meses até a cidade de Luanda. O embaixador levava uma carta do seu rei para o governador geral de Angola manifestando o interesse de que "fossem os brancos fazer negócio à sua Corte, como era costume antigo".101 Presume-se que, após alguns anos de investidas "diplomáticas" dos missionários e, muito possivelmente, dos novos interesses políticos do mani Congo que chegou ao poder em 1784, foi possível um gesto concreto no sentido do restabelecimento das boas relações comerciais de Luanda com o Congo. Como resultado deste gesto, Castello de Vide retornaria a São Salvador acompanhado do tenente Vicente José, encarregado de concretizar os negócios com o Congo. Negócios do tráfico, evidentemente, mas interpretados numa chave religiosa. Castello de Vide abominava a venda de escravos, muitos deles cristãos, aos hereges (ingleses, holandeses, franceses), pois acreditava ser menos mal que fossem vendidos aos portugueses "porque eram Cristãos". ${ }^{102}$ Entretanto, os negócios dos portugueses no Congo não correram nada bem. As cargas trazidas de Luanda foram surrupiadas em quantidade na viagem para o Congo. Assim, além de diminutas, as mercadorias dos portugueses não faziam frente aos negócios que alimentavam a demanda por escravos dos ingleses, franceses e holandeses. Desgostosos com o fracasso dos negócios e amedrontados com mais uma crise sucessória detonada com a morte do rei d. Afonso V, os militares e comerciantes de Luanda abandonaram o Congo e foram, por duas vezes, escoltados até as imediações do território de Angola pelo padre Godinho.

Nestes tempos, os missionários já eram capazes de reconhecer os "maus" intérpretes e, em algumas situações do cotidiano, prescindir da intermediação dos línguas. ${ }^{103}$ Assim como Castello de Vide, o conhecimento e certo domínio de Godinho sobre a "língua do Congo" - especialmente do kikongo falado em Mbanza Congo e em suas imediações - lhe permitiu pregar e também negociar acordos e salvo-condutos em terras do Reino. ${ }^{104}$

Entretanto, após a morte de Afonso V, a defesa dos interesses portugueses tornava-se cada vez mais difícil. O novo rei, na verdade um homem em idade avançada, parecia eclipsado pelos maiores do reino. Segundo Castello de Vide, naquela conjuntura, era o Conselho e principalmente os marqueses

\footnotetext{
${ }^{101}$ Viagem do Congo do missionário fr. Rafael Castello de Vide, op. cit., p. 239. ${ }^{102}$ Viagem do Congo do missionário fr. Rafael Castello de Vide, op. cit., p. 240. ${ }^{103}$ Viagem do Congo do missionário fr. Rafael Castello de Vide, op. cit., p. 212. ${ }^{104}$ Viagem do Congo do missionário fr. Rafael Castello de Vide, op. cit., p. 273.
} 
de Vunda, Ololo e Embo que governavam o Congo. Aquele foi também um momento importante de afirmação dos negócios com os portos ao norte do Congo. São Salvador andava cheia de comerciantes vili "carregados de fazendas para comprarem escravos". ${ }^{105}$

Os comerciantes vili, da costa do Loango, ao norte do rio Congo, foram sustentáculos fundamentais do tráfico para os portos do norte do Congo no século XVIII. ${ }^{106}$ Na verdade, este grupo tornou-se importante intermediário no tráfico transatlântico, especialmente entre os séculos XVII e XIX, respondendo de forma ágil e eficiente às novas oportunidades comerciais criadas com a chegada de navios europeus às costas do Congo e do Loango. Os primeiros contatos dos vili com o comércio transatlântico ocorrem no século XVII, atendendo a demanda dos navios holandeses por panos de ráfia, marfim e cobre. As caravanas vili percorriam distâncias imensas pelo interior do Congo até os mercados de Maleba Pool em busca de cobre. Em consequência, seus ferreiros e comerciantes monopolizavam não apenas o acesso ao minério, mas também seu transporte e comercialização na costa atlântica. A partir da segunda metade do século XVII, o comércio de escravos começava a propiciar mais lucros do que as tradicionais mercadorias controladas pelos vili. Desde então, os vili constituíram-se na principal rede de abastecimento de escravizados para holandeses, franceses e ingleses que aportavam nas costas do Loango e do Congo. Muitos comerciantes vili se fixaram nos arredores de Mbanza Congo, constituindo sólidas alianças comerciais com os maiores do Congo. ${ }^{107}$

Após enfrentar e evidentemente perder o enfrentamento com os poderosos negociantes do Congo associados aos vili, em junho de 1788, Castello de Vide, muito debilitado, deixa a missão do Congo. O padre Godinho, com cerca de 68 anos de idade, decide permanecer. André do Couto Godinho morreu no Congo, acredita-se que por volta de 1790. Sua permanência de livre e espontânea vontade nas terras do reino parece remeter a sua apresentação às au-

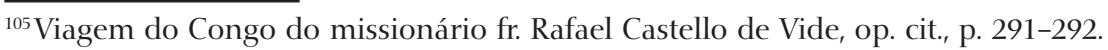

${ }^{106}$ Segundo Dias, "Entre os séculos XVI e XIX, a costa africana ao norte do rio Congo dividiu-se politicamente entre os três Estados de Loango, Nygoyo e Kakonda, cujas populações de língua kikongo compartilhavam interesses econômicos e tradições sociais e culturais comuns com as populações vizinhas de uma extensa região mais ao sul e a leste". DIAS, Jill R. Novas identidades africanas em Angola no contexto do comércio atlântico. In: BASTOS, Cristina; ALMEIDA, Miguel Vale de; FELDMAN- BIANCO, Bela. Trânsitos coloniais. Diálogos críticos luso-brasileiros. Campinas/ SP: Editora da Unicamp, 2007, p. 319.

${ }^{107}$ DIAS, Jill R. Novas identidades africanas em Angola no contexto do comércio atlântico, op. cit., p. 319-321.
} 
toridades do Reino de Angola, no ano de 1779, onde ficaram registrados seus "ardentes desejos de ir à missão no Congo". É possível que o padre Godinho não tenha apenas escolhido viver, mas também morrer nas terras do Congo.

Como mencionei algumas páginas atrás, no ano de 1858, o militar português tenente Zacharias da Silva Cruz, chefe de uma expedição exploratória à cidade de São Salvador, antiga capital do Reino do Congo, encontrou objetos e registros que testemunhavam a residência do padre Godinho no povoado de Kinganga. ${ }^{108}$ Diante de vários objetos do culto católico, além de alguns escritos e correspondências, entre estes uma certidão e uma carta assinadas pelo padre Godinho, Cruz não reconheceu nenhuma importância histórica, devolvendo-os ao soba da localidade. Contrariando a percepção do militar português, a autora buscou neste artigo demonstrar a importância histórica e o potencial investigativo da trajetória de André do Couto Godinho para a história social das populações de cor o mundo atlântico.

Recebido: 24/08/2014 - Aprovado: 10/06/2015

\footnotetext{
${ }^{108}$ “Extracto de um relatório do chefe do concelho de D. Pedro 5. ${ }^{\circ}$, o tenente Zacharias da Silva Cruz, sobre a sua viagem a S. Salvador do Congo".
} 